\title{
Activatable Water Soluble Probes Enhance Tumor Imaging by Responding to Dysregulated pH and Exhibiting High Tumor-to-liver Fluorescence Emission Contrast
}

Hu Xiong, Petra Kos, Yunfeng Yan, Kejin Zhou, Jason B. Miller, Sussana Elkassih, and Daniel J. Siegwart*

The University of Texas Southwestern Medical Center, Simmons Comprehensive Cancer Center, Department of Biochemistry, Dallas, Texas 75390, United States. *Correspondence should be addressed to daniel.siegwart@utsouthwestern.edu

\section{Supporting Information}

\section{Contents}

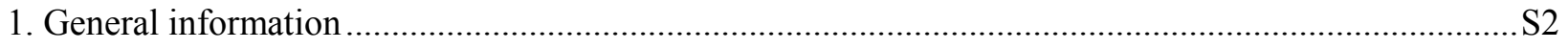

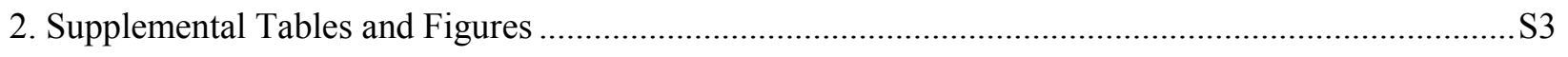

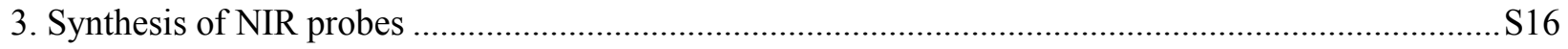

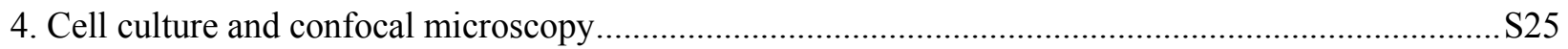

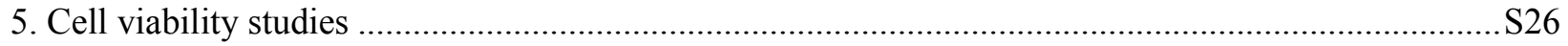

6. In vivo imaging and biodistribution of breast, lung, and cervical tumor-bearing mice ......................S26

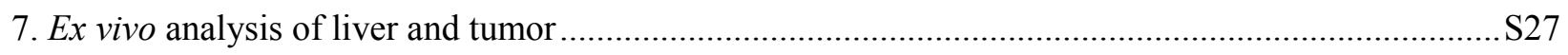

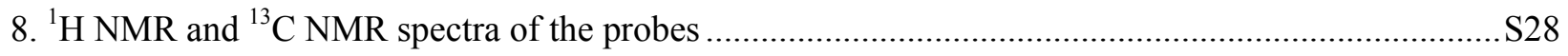

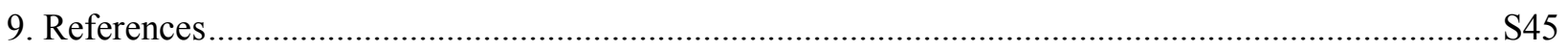




\section{General information}

Unless stated otherwise, all reactions were carried out under an atmosphere of argon using standard Schlenk techniques. All organic solvents were purchased from Fisher Scientific or Sigma Aldrich and purified with a solvent purification system (Innovative Technology). SulfoCyanine5 carboxylic acid was purchased from Lumiprobe Corporation. Indocyanine green was purchased from Fisher Scientific. Dulbecco's Modified Eagle Medium (DMEM), RPMI-1640 Medium, and fetal bovine serum (FBS) were purchased from Sigma-Aldrich. LysoTracker Green and DAPI were purchased from Life Technologies. Sephadex LH-20 was purchased from GE Healthcare. ${ }^{1} \mathrm{H}$ NMR spectra were recorded on a Varian Mercury $500 \mathrm{MHz}$ or Agilent Mercury $400 \mathrm{MHz}$ spectrometer in chloroform-d or methanol-d. All signals were reported in ppm with chloroform signal at $7.26 \mathrm{ppm}$ or methanol signals at 3.31, $4.87 \mathrm{ppm}$ as a standard. Data for ${ }^{1} \mathrm{H}$ NMR were recorded as follows: chemical $\operatorname{shift}(\delta, \mathrm{ppm})$, multiplicity $(\mathrm{s}=\operatorname{singlet}, \mathrm{d}=$ doublet, $\mathrm{t}=$ triplet, $\mathrm{q}=$ quartiplet, $\mathrm{m}=$ multiplet or unresolved, coupling constant(s) in $\mathrm{Hz}$, integration). ${ }^{13} \mathrm{C}$ NMR spectra were recorded on an Agilent Mercury $400 \mathrm{MHz}$ spectrometer in chloroform-d. All signals are reported in ppm with the internal chloroform signal at $77.0 \mathrm{ppm}$ as a standard. Column chromatography was performed either manually or on a Teledyne-Isco CombiFlash. The fluorescence emission spectra were obtained on a Hitachi fluorometer (F-7500 model). The UVVis spectroscopy study was performed on a Shimadzu UV-Vis spectrophotometer (UV-1800 model). Confocal microscopy imaging was performed using a Zeiss LSM 700 Confocal and images were analyzed using ImageJ (NIH). The whole body and ex vivo organ fluorescence imaging was performed on an IVIS Lumina System (Caliper Life Sciences). Luminescence measurements were performed on a Tecan InfiniTe F/M200 Pro microplate reader. 


\section{Supplemental Tables and Figures}

2.1 Modified reaction conditions of Knoevenagel condensation. ${ }^{a}$

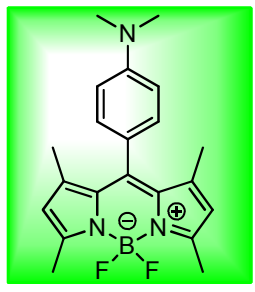

$1 \mathrm{~b}$

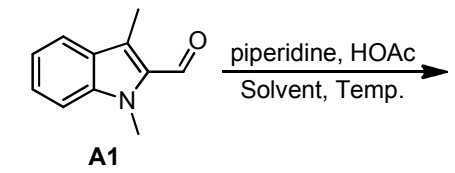

A1
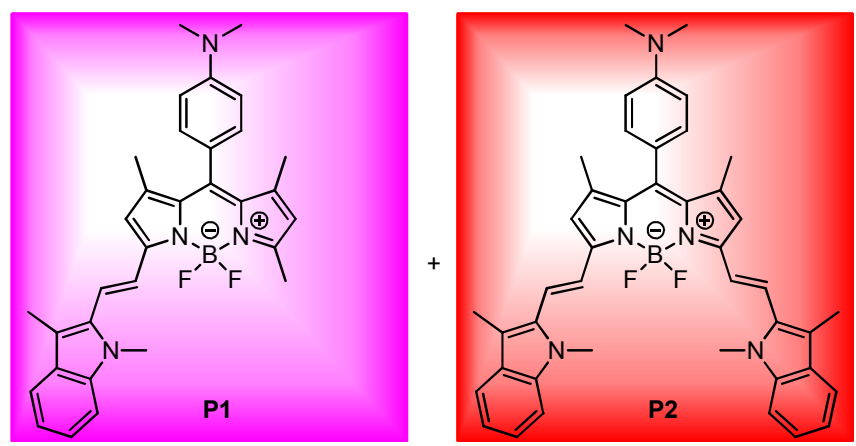

Table S1. Reaction optimization of Knoevenagel condensation reaction.

\begin{tabular}{cccccc}
\hline Entry & Solvent & Temp. $\left({ }^{\circ} \mathrm{C}\right)$ & Time $(\mathrm{h})$ & Product & Conversion \\
\hline 1 & Toluene & 120 & 24 & $\mathrm{P} 1, \mathrm{P} 2$ & $--^{\mathrm{c}}$ \\
$2^{\mathrm{b}}$ & Toluene & 120 & 24 & $\mathrm{P} 1, \mathrm{P} 2$ & $-{ }^{\mathrm{c}}$ \\
3 & EtOH & 85 & 24 & $\mathrm{P} 1, \mathrm{P} 2$ & $-{ }^{\mathrm{c}}$ \\
4 & $\mathrm{CH}_{3} \mathrm{CN}$ & 85 & 1.5 & $\mathrm{P} 1$ & $>80 \%$ \\
5 & $\mathrm{CH}_{3} \mathrm{CN}$ & 85 & 8 & $\mathrm{P} 2$ & $>90 \%$ \\
\hline
\end{tabular}

${ }^{a}$ Reaction conditions: $1 \mathbf{b}(0.03 \mathrm{mmol})$, A1 $(0.18 \mathrm{mmol})$, piperidine $(60 \mu \mathrm{L})$, and HOAc $(36 \mu \mathrm{L})$ in solvent $(1 \mathrm{~mL})$ with $4 \AA$ molecular sieves. ${ }^{b}$ Piperidine/TsOH as catalyst. ${ }^{c}$ Not determined.

The condensation of a tetramethyl-BODIPY scaffold with an aromatic aldehyde was usually refluxed in dry toluene in the presence of piperidine and glacial acetic acid (classic Knoevenagel conditions). ${ }^{[1-4]}$ Any water formed during the reaction was removed azeotropically by heating in a Dean-Stark apparatus. However, these reactions usually require high temperature and long reaction time. Moreover, the conversions for such reactions were low. ${ }^{[1-4]}$ After screening, we found acetonitrile was the optimized solvent for such condensation reactions. P1 was mainly formed after $1.5 \mathrm{~h}$ in refluxing $\mathrm{CH}_{3} \mathrm{CN}$ (entry 4). However, $\mathbf{P 2}$ could be mainly obtained after an extended reaction time ( $8 \mathrm{~h}$, entry 5$)$. 
2.2 Photo-physical properties of NIR BODIPYs.

Table S2. Spectroscopic properties of $\mathbf{2 b}, \mathbf{3 b}$, and $\mathbf{5 a - e}$.

\begin{tabular}{cccccc}
\hline Probe & Solvent & $\lambda_{\text {abs, } \max }(\mathrm{nm})^{\mathrm{a}}$ & $\lambda_{\text {em } \max }(\mathrm{nm})^{\mathrm{b}}$ & ${\Phi_{\mathrm{FL}}}^{\mathrm{c}}$ & $\mathrm{pK}_{\mathrm{a}}$ \\
\hline $\mathbf{2 b}$ & $\mathrm{DMSO}$ & 705 & 746 & $-^{\mathrm{d}}$ & \\
$\mathbf{3 b}$ & $\mathrm{DMSO}$ & 660 & 730 & $-^{\mathrm{d}}$ & \\
$\mathbf{5 a}$ & $\mathrm{H}_{2} \mathrm{O}$ & 645 & 660 & 0.09 & \\
$\mathbf{5 b - 1}$ & $\mathrm{H}_{2} \mathrm{O}$ & 640 & 651 & $0.18^{\mathrm{e}}$ & 2.9 \\
$\mathbf{5 b - 2}$ & $\mathrm{H}_{2} \mathrm{O}$ & 648 & 668 & $0.23^{\mathrm{e}}$ & 3.1 \\
$\mathbf{5 c}$ & $\mathrm{H}_{2} \mathrm{O}$ & 648 & 670 & $0.22^{\mathrm{e}}$ & 4.5 \\
$\mathbf{5 d}$ & $\mathrm{H}_{2} \mathrm{O}$ & 648 & 667 & $0.23^{\mathrm{f}}$ & 1.75 \\
$\mathbf{5 e}$ & $\mathrm{H}_{2} \mathrm{O}$ & 648 & 668 & $0.25^{\mathrm{e}}$ & 4.0 \\
\hline
\end{tabular}

${ }^{a}$ The UV-Vis spectroscopy study was performed on a Shimadzu UV-Vis spectrophotometer (UV-1800 model). ${ }^{b}$ The fluorescence emission spectra were obtained on a Hitachi fluorometer (F-7500 model). ${ }^{c}$ The reported quantum yield was calculated according to the following equation: $\Phi_{\text {sample }}=\Phi_{\text {standard }}\left(\mathrm{A}_{\text {standard }} / \mathrm{A}_{\text {sample }}\right)\left(\mathrm{F}_{\text {sample }} / \mathrm{F}_{\text {standard }}\right)\left(\mathrm{n}_{\text {sample }} / \mathrm{n}_{\text {standard }}\right)^{2}$, where " $\Phi$ " is the quantum yield, " $\mathrm{A}$ " is the absorbance at the excitation frequency, " $\mathrm{F}$ " is the integrated area under the emission curve, and "n" is the refractive index of the solvent used. Sulfo-Cyanine5 carboxylic acid (sulfo-Cy5) $\left(\Phi_{\mathrm{fl}}=0.2\right)$ in water was used as the fluorescence standard. ${ }^{d} \mathrm{Not}$ determined. ${ }^{e}$ In $0.01 \mathrm{M}$ aqueous $\mathrm{HCl} .{ }^{f}$ In $0.1 \mathrm{M}$ aqueous $\mathrm{HCl}$.

2.3 Supplemental Figures.
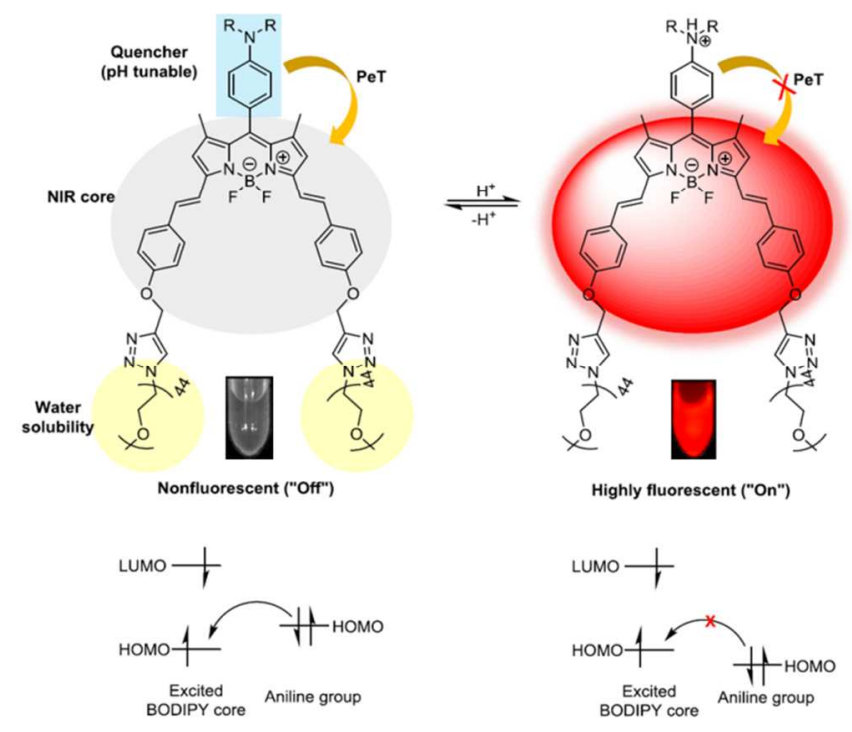

Figure S1. Water-soluble PEGylated NIR BODIPYs activate in response to a decrease in $\mathrm{pH}$ by photo-induced electron transfer (PeT) mechanism. Electron flow is involved in a PeT process from the aniline group to the excited BODIPY core as shown in the frontier molecular orbital diagram. 

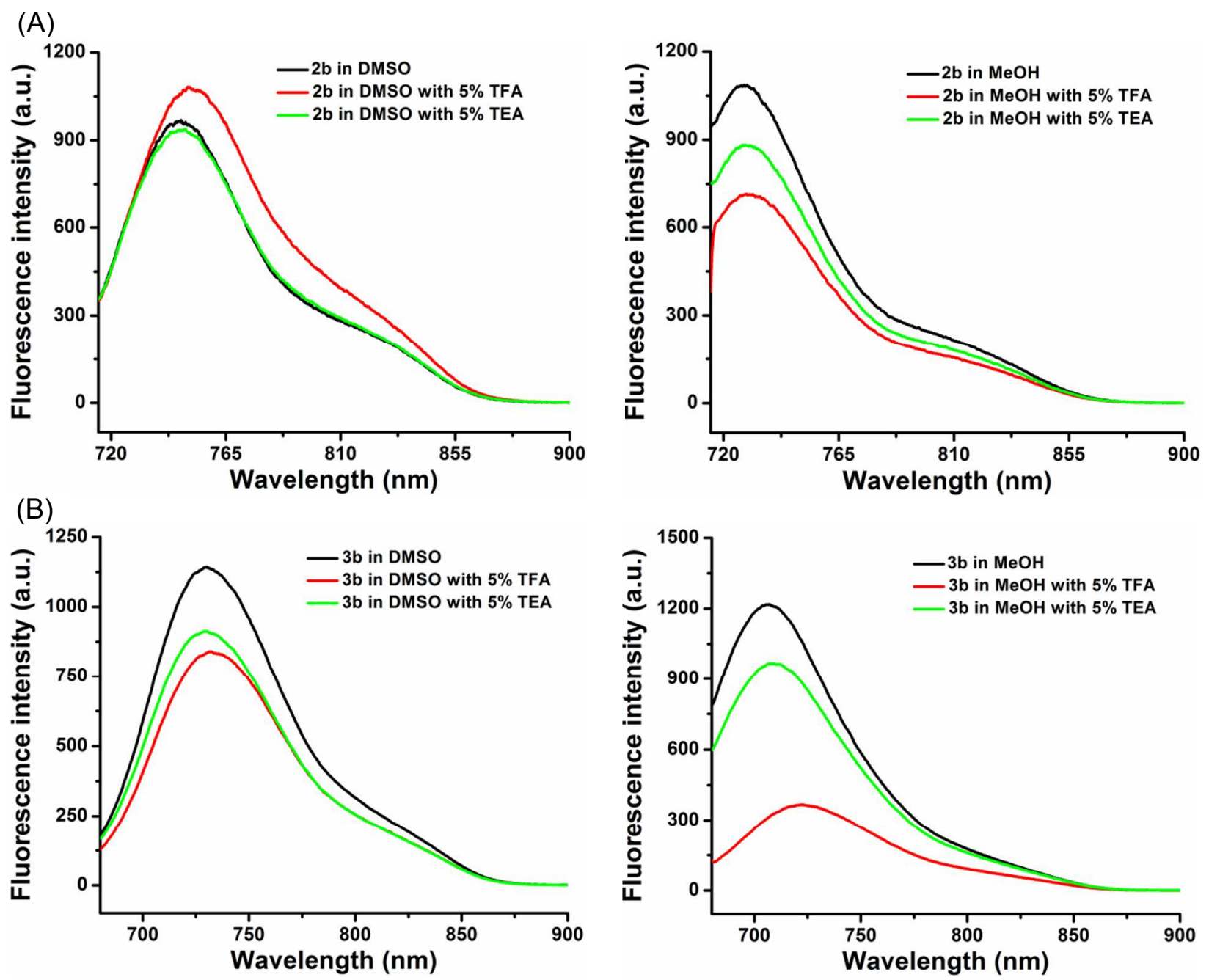

Figure S2. (A) Fluorescence emission spectra of $\mathbf{2 b}$ in DMSO $(10 \mu \mathrm{M})$ and $\mathrm{MeOH}(10 \mu \mathrm{M})$. Each sample was excited at $705 \mathrm{~nm}$, and emission spectra were collected from 715 to $900 \mathrm{~nm}$. (B) Fluorescence emission spectra of $\mathbf{3 b}$ in DMSO $(10 \mu \mathrm{M})$ and $\mathrm{MeOH}(10 \mu \mathrm{M})$. Each sample was excited at $660 \mathrm{~nm}$, and emission spectra were collected from 680 to $900 \mathrm{~nm}$. 

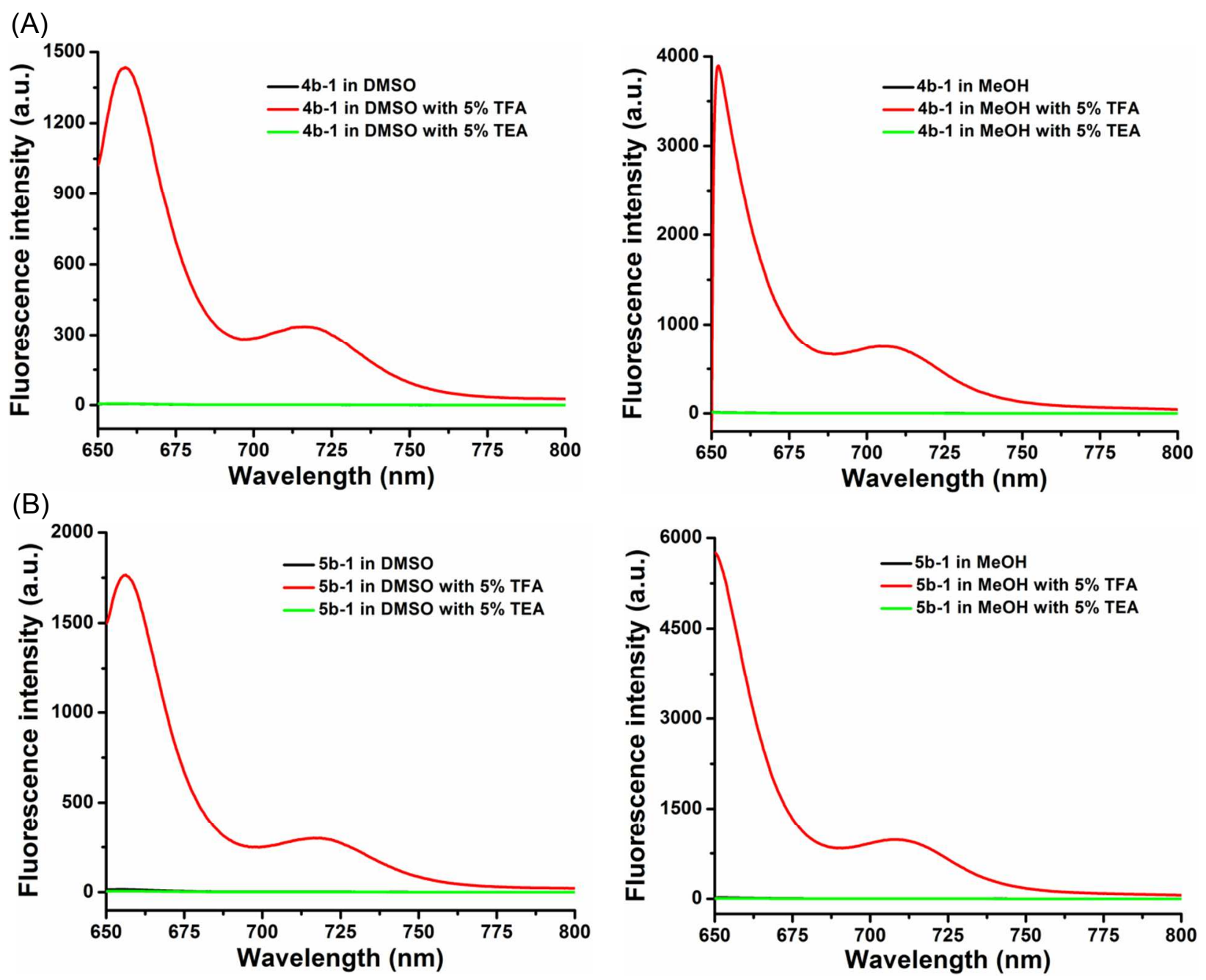

Figure S3. (A) Fluorescence emission spectra of 4b-1 in DMSO $(10 \mu \mathrm{M})$ and $\mathrm{MeOH}(10 \mu \mathrm{M})$. 4b-1 can only turn on in acidic DMSO or MeOH. Each sample was excited at $640 \mathrm{~nm}$, and emission spectra were collected from 650 to $800 \mathrm{~nm}$. (B) Fluorescence emission spectra of 5b-1 in DMSO $(10 \mu \mathrm{M})$ and $\mathrm{MeOH}(10 \mu \mathrm{M})$. 5b-1 can only turn on in acidic DMSO or MeOH. Each sample was excited at $640 \mathrm{~nm}$, and emission spectra were collected from 650 to $800 \mathrm{~nm}$. 

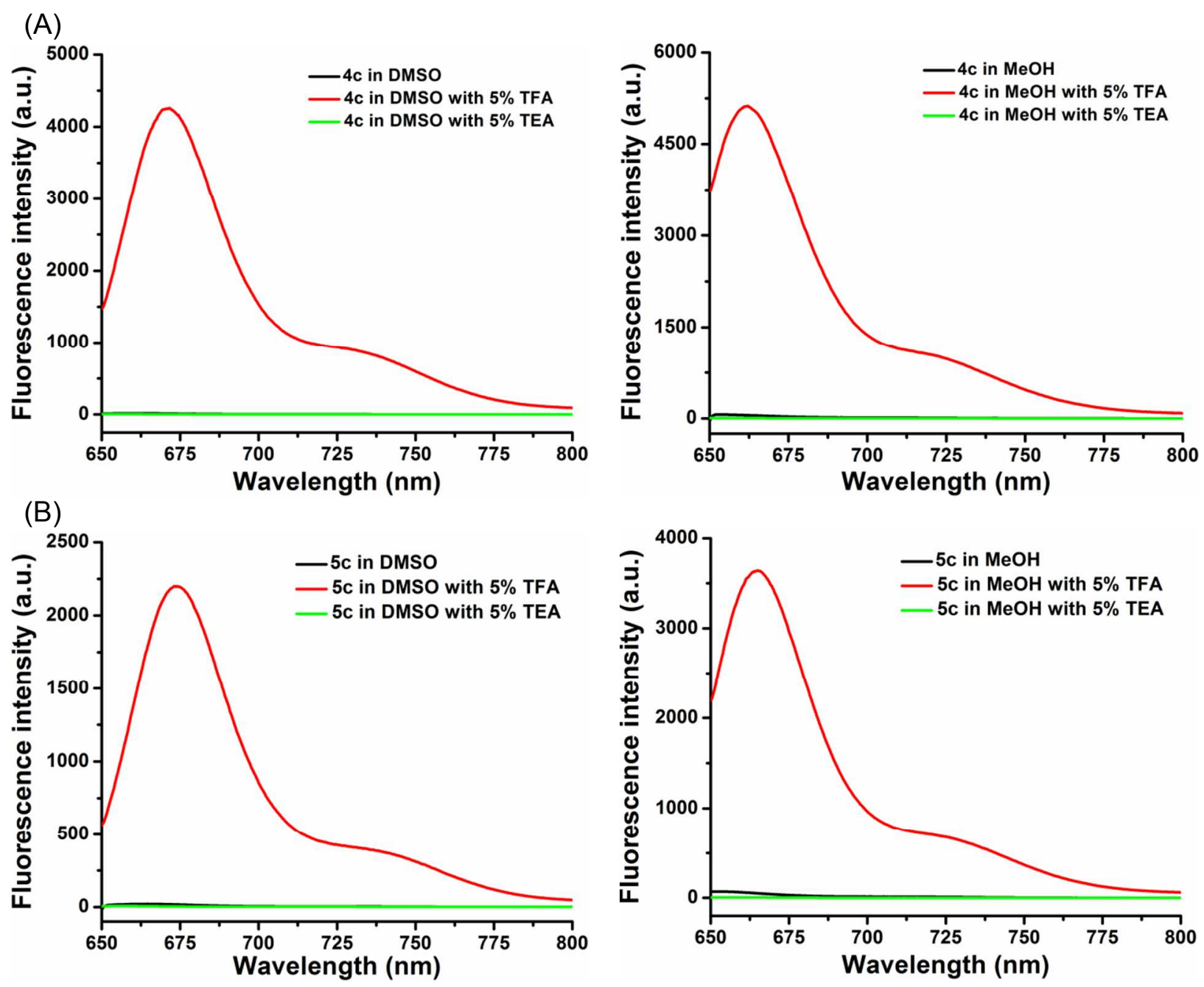

Figure S4. To help understand the origin of the increased T/L ratio, the tumor and liver were homogenized and $\mathbf{5 c}$ was extracted into methanol to completely isolate $\mathbf{5 c}$. Probe $\mathbf{5 c}$ is off in neutral methanol, but will immediately turn on in acidic methanol. Thus, we were able to calibrate and quantify the total uptake of $\mathbf{5 c}$ in the tissues after adding a small amount of trifluoroacetic acid (TFA) to the methanol extracts. (A) Fluorescence emission spectra of $\mathbf{4 c}$ in DMSO $(10 \mu \mathrm{M})$ and $\mathrm{MeOH}(10 \mu \mathrm{M}) .4 \mathbf{c}$ can only turn on in acidic DMSO or MeOH. Each sample was excited at $640 \mathrm{~nm}$, and emission spectra were collected from 650 to $800 \mathrm{~nm}$. (B) Fluorescence emission spectra of $\mathbf{5 c}$ in DMSO $(10 \mu \mathrm{M})$ and MeOH $(10 \mu \mathrm{M})$. $\mathbf{5 c}$ can only turn on in acidic DMSO or $\mathrm{MeOH}$. Each sample was excited at $640 \mathrm{~nm}$, and emission spectra were collected from 650 to $800 \mathrm{~nm}$. 


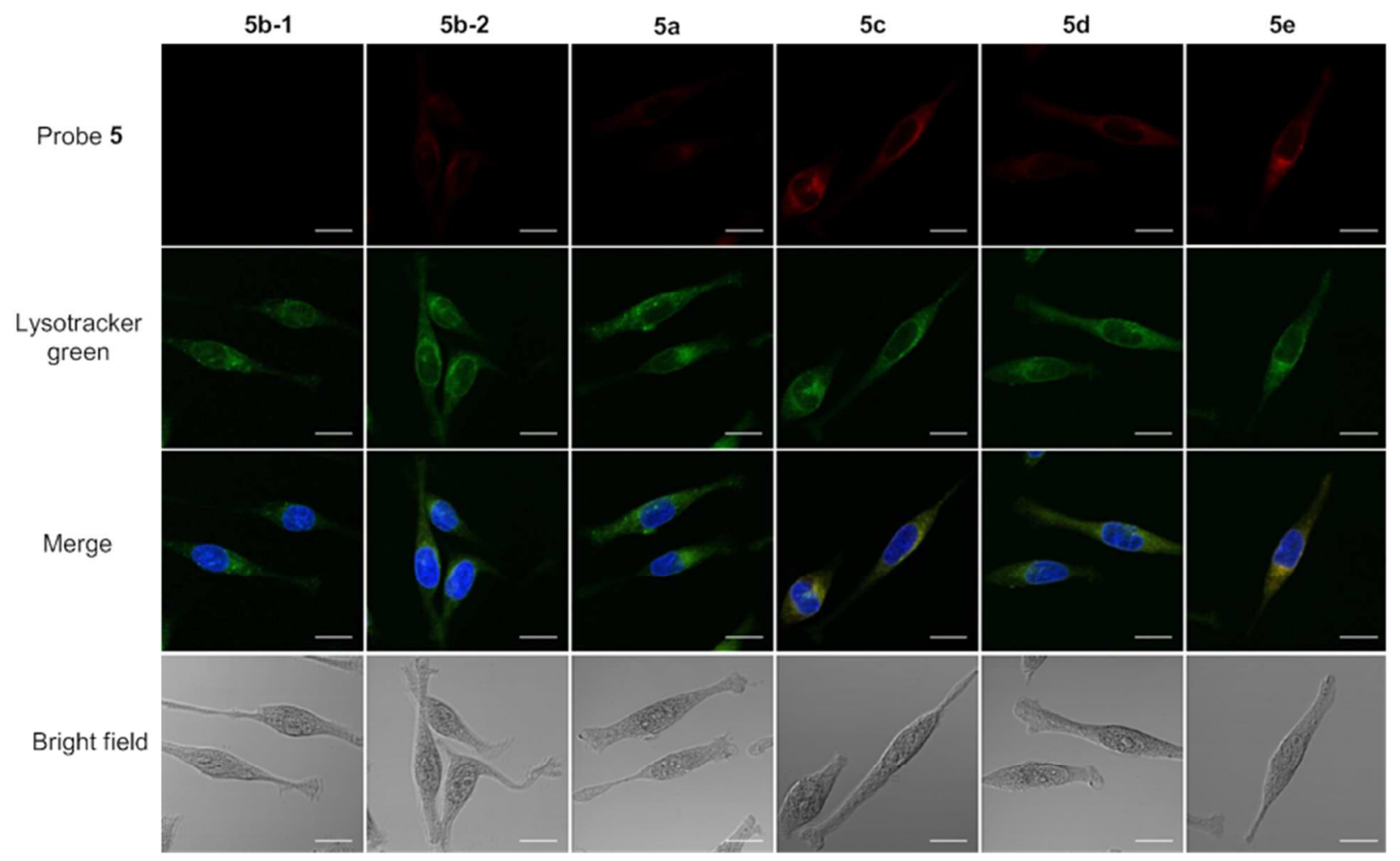

Figure S5. Confocal fluorescence microscope images (20X) of the 5 series of probes in Hela cells. Cells $\left(10,000\right.$ cells/well) were incubated with $5(5.0 \mu \mathrm{M})$ for $30 \mathrm{~min}$ at $37{ }^{\circ} \mathrm{C}$, and the media was replaced with fresh media containing lysotracker green $(0.5 \mu \mathrm{M})$ and incubated for 20 min. Then the cells were fixed with $4 \%$ paraformaldehyde. Cell nucleus was stained with DAPI $(0.3 \mu \mathrm{M})$. The NIR probe is red; lysosomes are green; and the cell nuclei are blue. Colocalization is seen as yellow. 5a did not exhibit bright fluorescence due to low quantum yield and uptake in short time. Scale bar $=20 \mu \mathrm{m}$. 


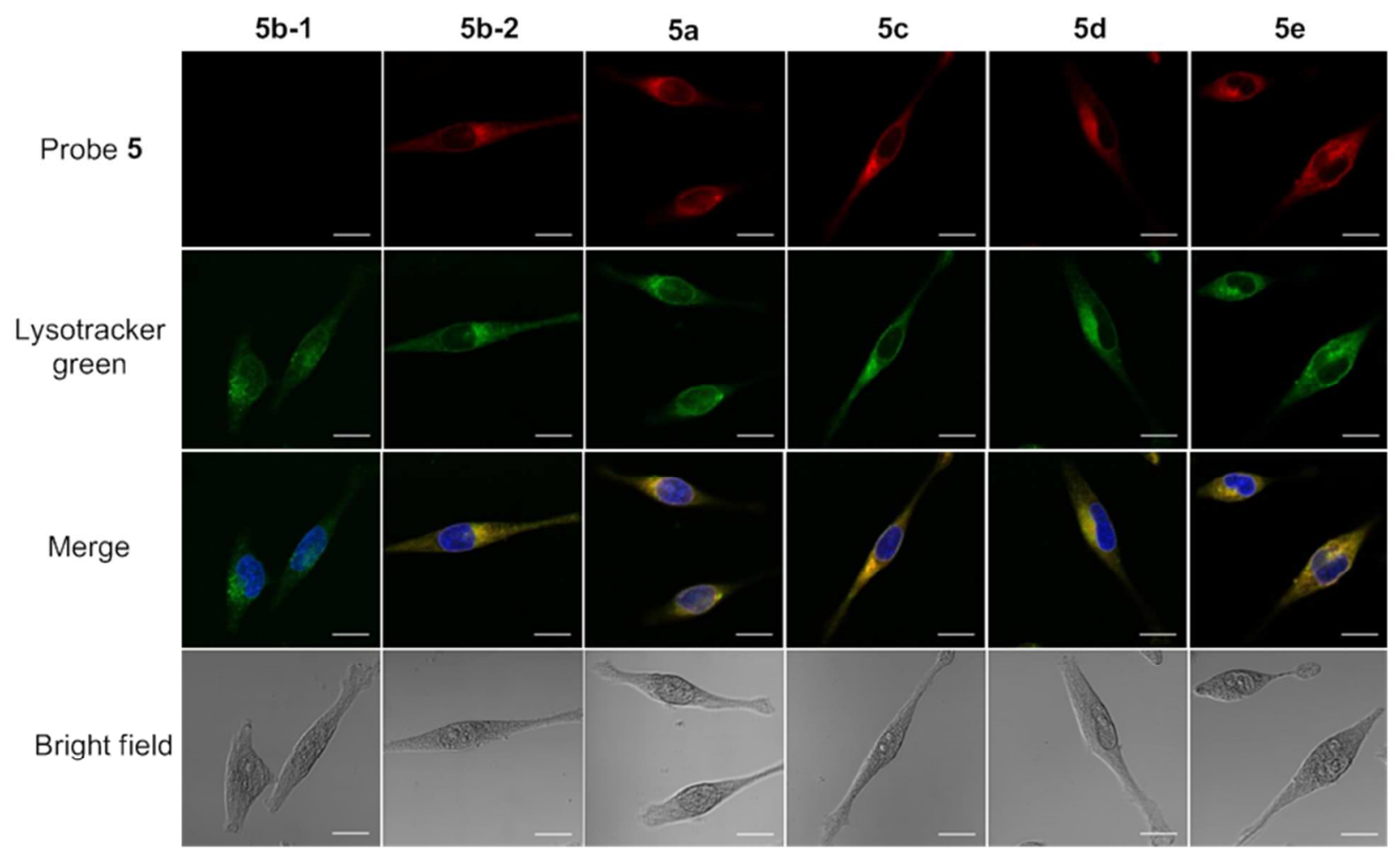

Figure S6. Confocal fluorescence microscope images (20X) of the 5 series of probes in Hela cells. Cells $\left(10,000\right.$ cells/well) were incubated with $5(5.0 \mu \mathrm{M})$ for $4 \mathrm{~h}$ at $37{ }^{\circ} \mathrm{C}$, and the media was replaced with fresh media containing lysotracker green $(0.5 \mu \mathrm{M})$ and incubated for $30 \mathrm{~min}$. Then the cells were fixed with $4 \%$ paraformaldehyde. Cell nucleus was stained with DAPI $(0.3$ $\mu \mathrm{M})$. The NIR probe is red; lysosomes are green; and the cell nuclei are blue. Co-localization is seen as yellow. Scale bar $=20 \mu \mathrm{m}$. 


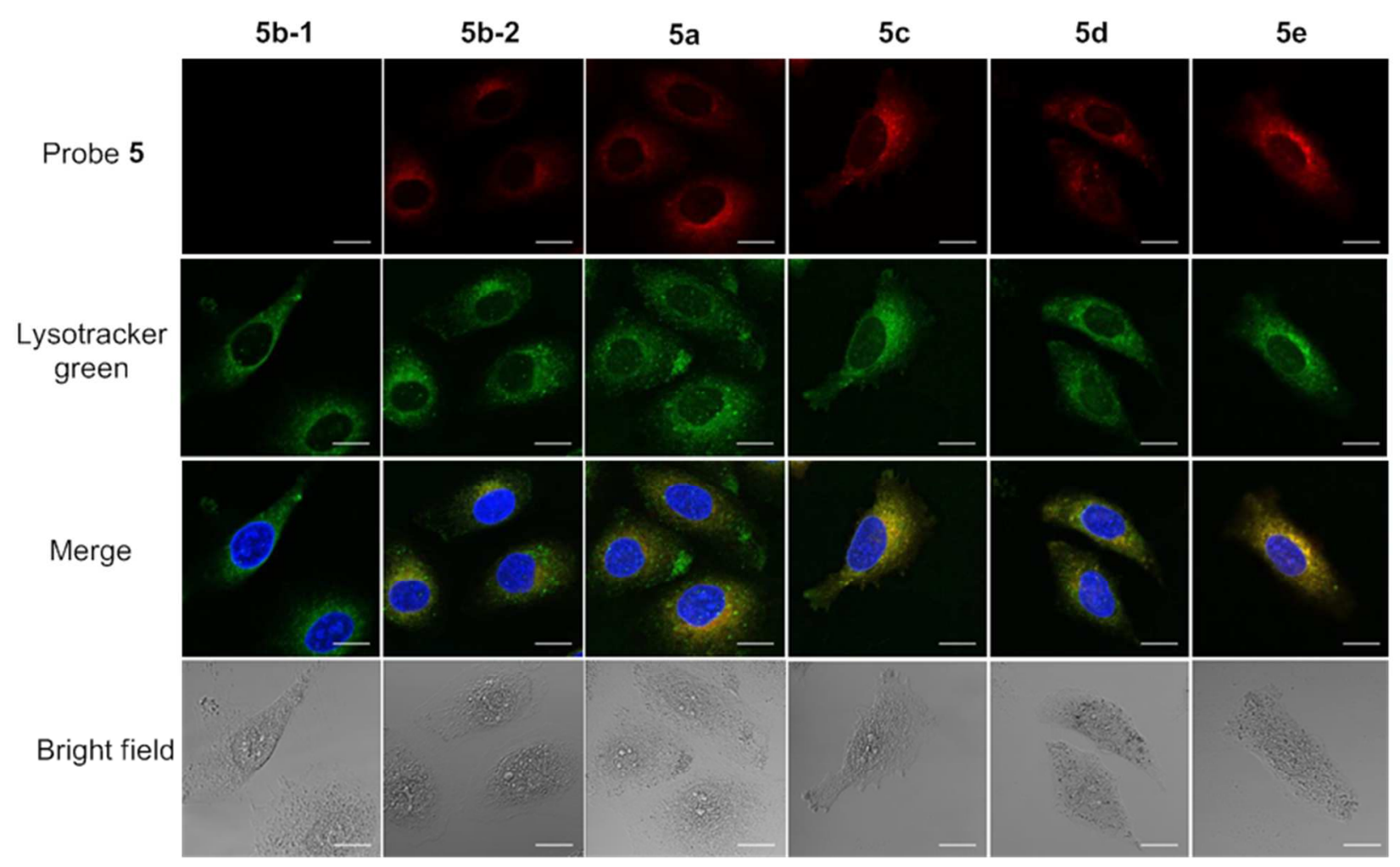

Figure S7. Confocal fluorescence microscope images (20X) of the $\mathbf{5}$ series of probes in Huh7 cells. Cells $\left(10,000\right.$ cells/well) were incubated with $5(5.0 \mu \mathrm{M})$ for $4 \mathrm{~h}$ at $37{ }^{\circ} \mathrm{C}$, and the media was replaced with fresh media containing lysotracker green $(0.5 \mu \mathrm{M})$ and incubated for $30 \mathrm{~min}$. Then the cells were fixed with $4 \%$ paraformaldehyde. Cell nucleus was stained with DAPI $(0.3$ $\mu \mathrm{M})$. The NIR probe is red; lysosomes are green; and the cell nuclei are blue. Co-localization is seen as yellow. Scale bar $=20 \mu \mathrm{m}$. 


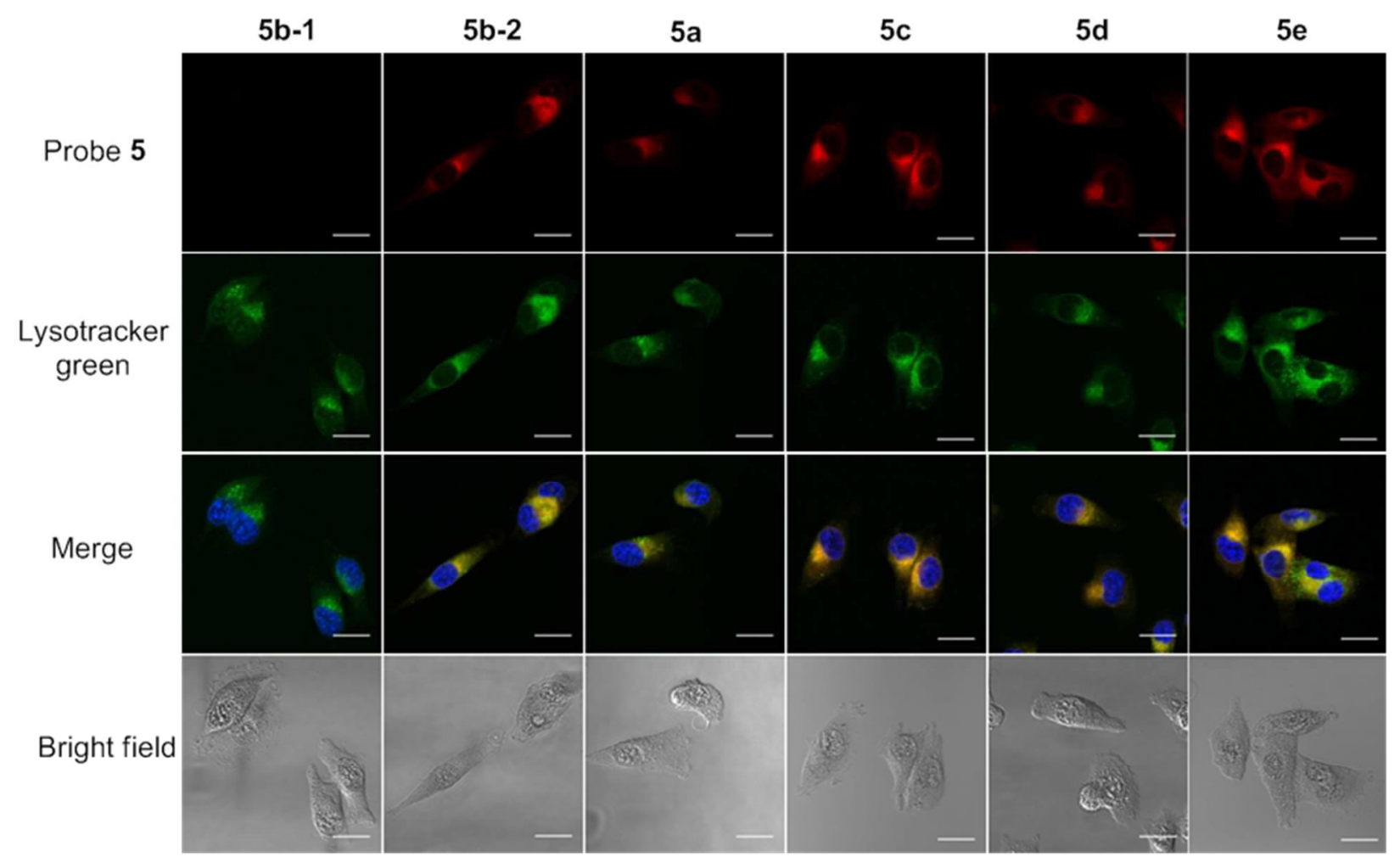

Figure S8. Confocal fluorescence microscope images (20X) of the 5 series of probes in HCC4017 cells. Cells $\left(10,000\right.$ cells/well) were incubated with $5(5.0 \mu \mathrm{M})$ for $4 \mathrm{~h}$ at $37^{\circ} \mathrm{C}$, and the media was replaced with fresh media containing lysotracker green $(0.5 \mu \mathrm{M})$ and incubated for $30 \mathrm{~min}$. Then the cells were fixed with $4 \%$ paraformaldehyde. Cell nucleus was stained with DAPI $(0.3 \mu \mathrm{M})$. The NIR probe is red; lysosomes are green; and the cell nuclei are blue. Colocalization is seen as yellow. Scale bar $=20 \mu \mathrm{m}$.

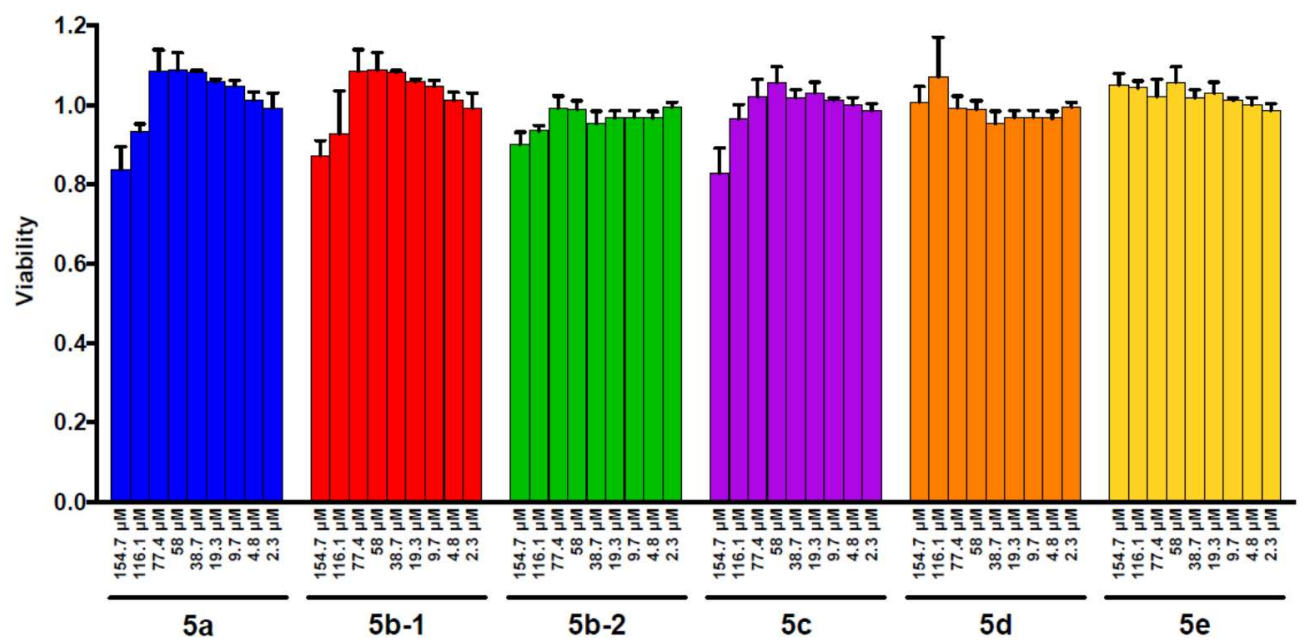

Figure S9. CellTiter-Glo luminescent cell viability assay in Hela cells. Cell viability was measured after addition of 5a-e with different concentrations and 24 hours incubation compared to untreated cells $(n=3)$. 
(A)
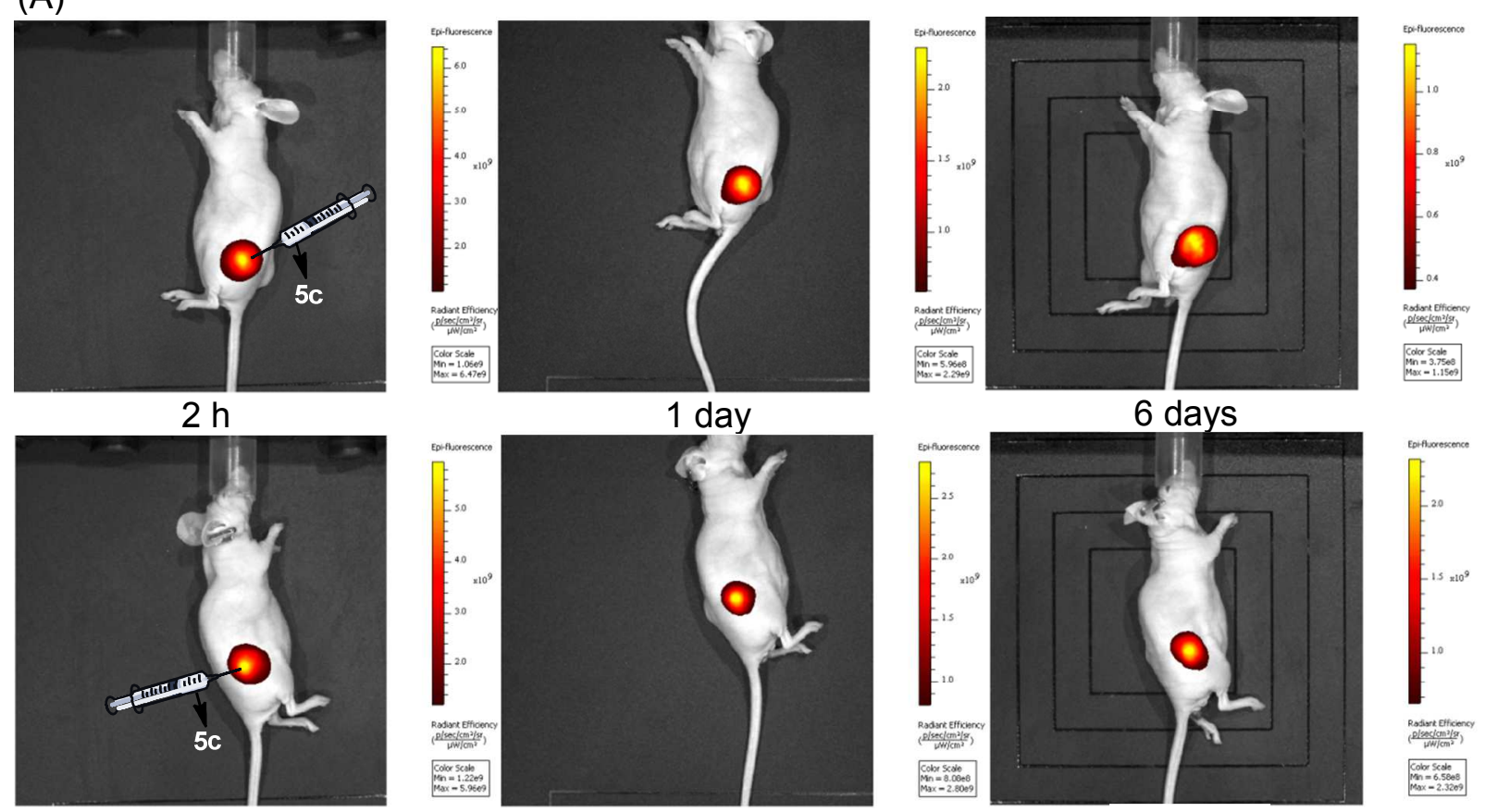

1 day

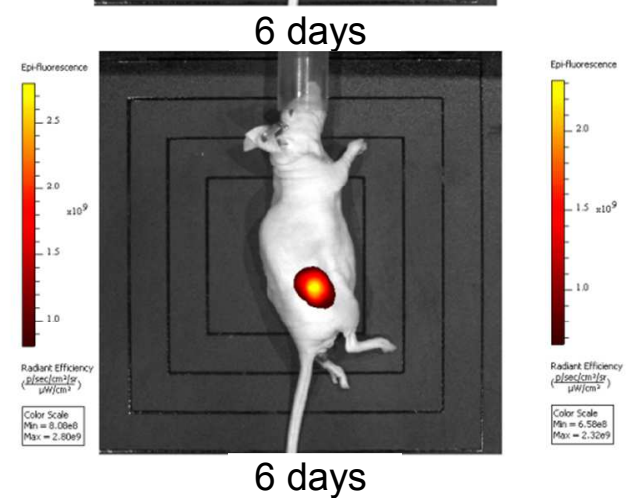

(B)
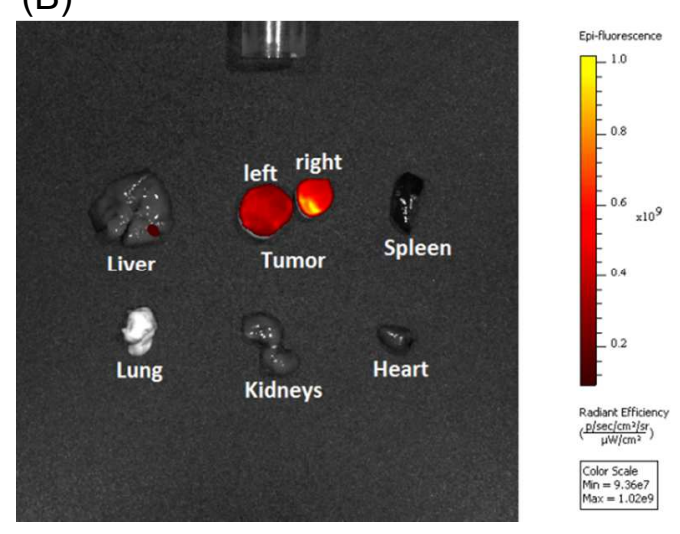

Figure S10. Probe 5c for MDA-MB-231 tumor imaging in vivo and ex vivo. (A) Nude mice bearing two MDA-MB-231 tumors were injected with a dosage of $0.5 \mathrm{mg} / \mathrm{kg} 5 \mathbf{c}(10 \mu \mathrm{M}, 200 \mu \mathrm{L}$ in PBS) via intratumoral injection. NIR fluorescence images at selected time-points were captured. (B) At 6 days post-injection, mice were sacrificed and organs were collected and imaged using an IVIS Lumina imaging system. 


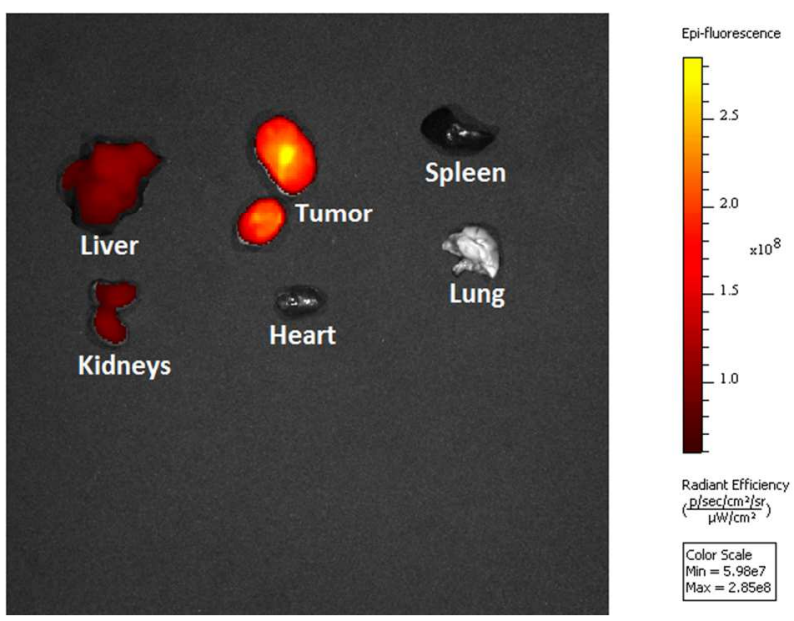

Figure S11. Representative ex vivo fluorescence images of harvested tumors and organs of MDA-MB-231 tumor-bearing mice sacrificed at $24 \mathrm{~h}$ post-injection. Nude mice bearing two MDA-MB-231 tumors were intravenously administered with probe 5c $(10 \mu \mathrm{M}, 200 \mu \mathrm{L}$ in PBS) at a dose of $0.5 \mathrm{mg} / \mathrm{kg}$ via the tail vein and, $24 \mathrm{~h}$ later, organs were collected for NIR imaging using an IVIS Lumina imaging system.
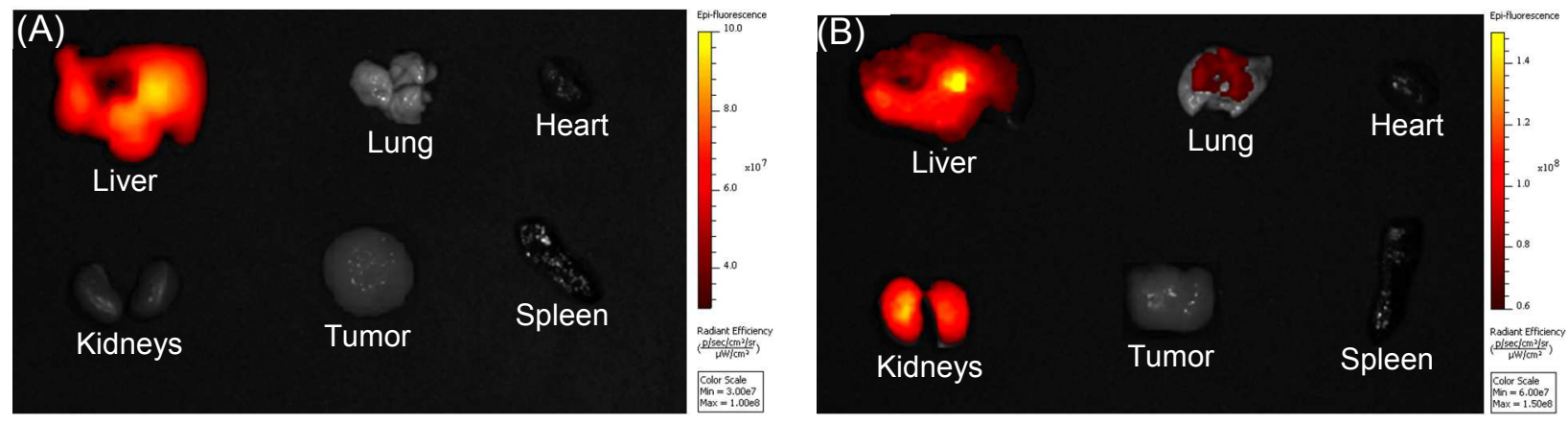

Figure S12. Representative ex vivo fluorescence images of collected tumors and organs of MDA-MB-231 tumor-bearing mice sacrificed at $15 \mathrm{~min}$ post-injection. (A) MDA-MB-231 tumor-bearing mice were intravenously injected with ICG $(10 \mu \mathrm{M}, 200 \mu \mathrm{L}$ in PBS) via the tail vein and, 15 min later, organs were collected for NIR imaging. (B) MDA-MB-231 tumor-bearing mice were intravenously injected with sulfo-Cy5 $(10 \mu \mathrm{M}, 200 \mu \mathrm{L}$ in PBS) via the tail vein and, 15 min later, organs were collected for NIR imaging. 


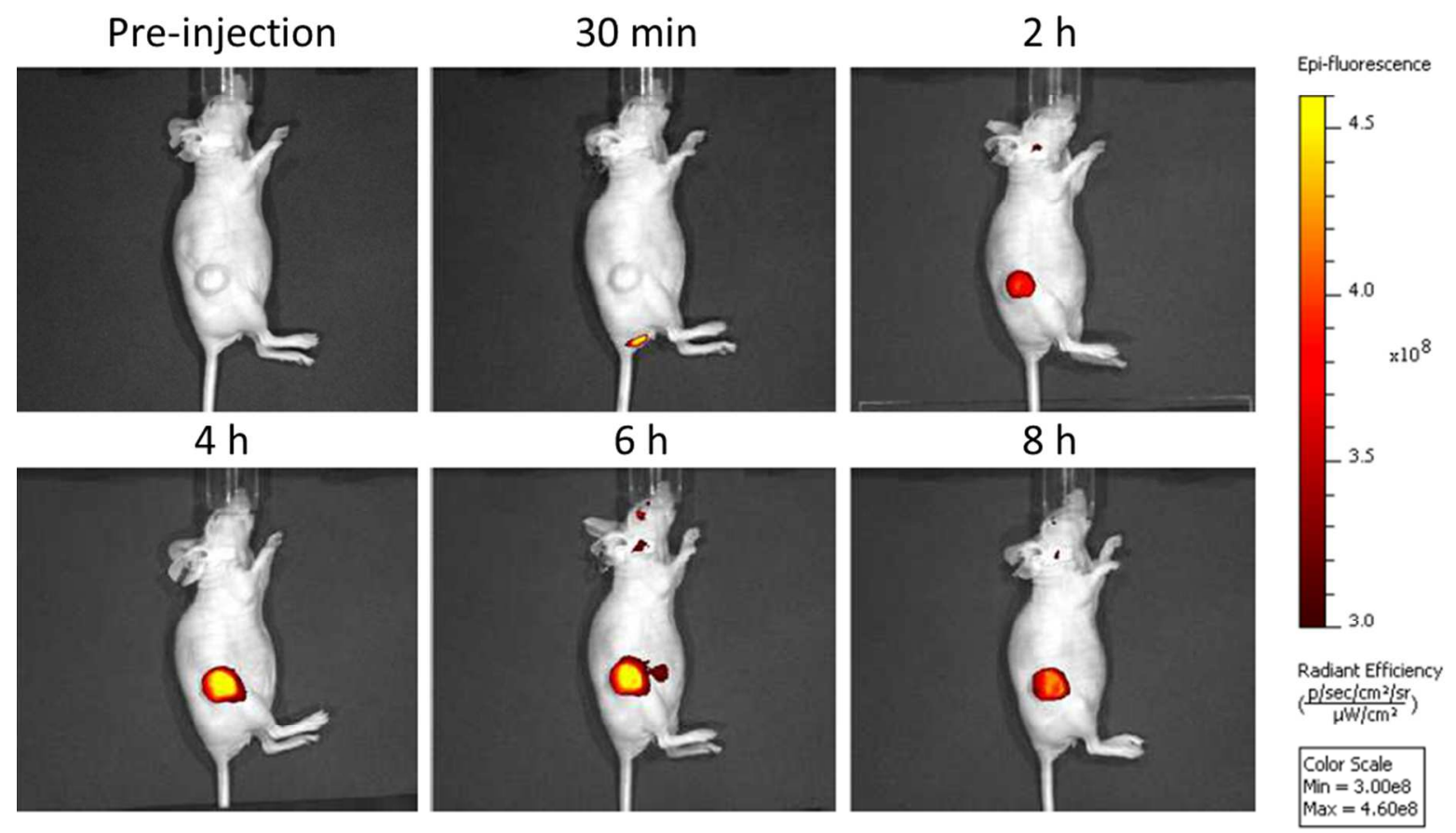

Figure S13. Time-dependent in vivo fluorescence images of subcutaneous HCC4017 tumorbearing mice after intravenous injection of $0.5 \mathrm{mg} / \mathrm{kg}(10 \mu \mathrm{M}, 200 \mu \mathrm{L}) \mathrm{pH}$-activatable probe 5c via the tail vein. 
(A) Pre-injection

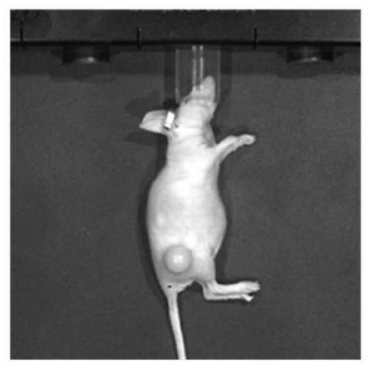

$4 \mathrm{~h}$

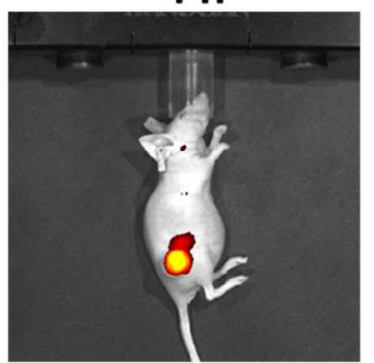

(B)

i.v. $8 \mathrm{~h}$

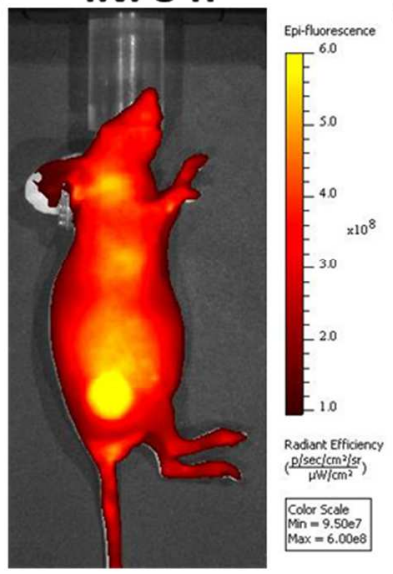

$30 \mathrm{~min}$

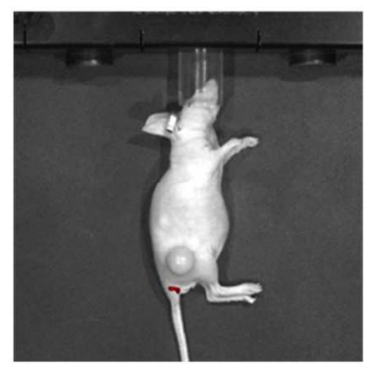

$6 \mathrm{~h}$

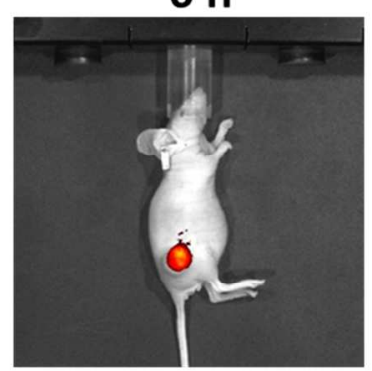

(C)

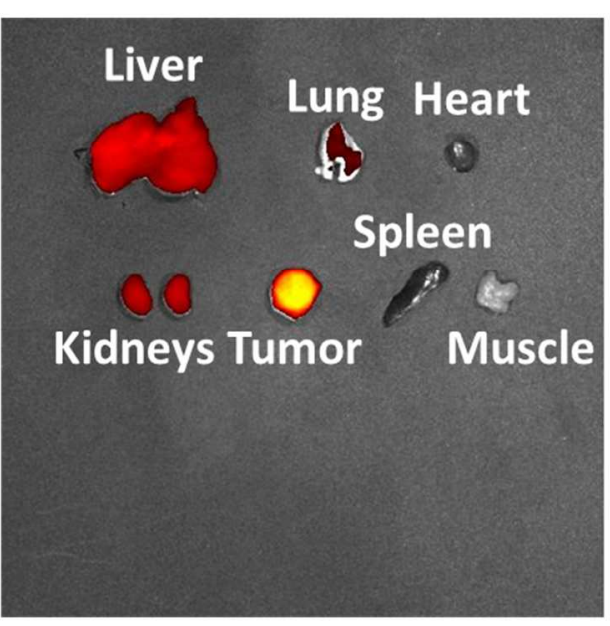

$2 \mathrm{~h}$

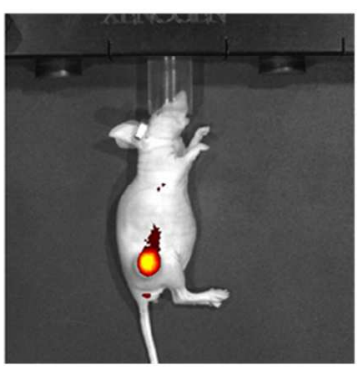

$8 \mathrm{~h}$

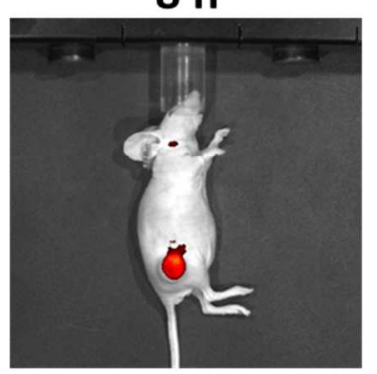

Epi-fluorescence

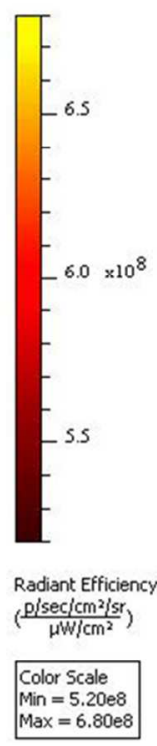

$\operatorname{Max}=6.80 \mathrm{e} 8$

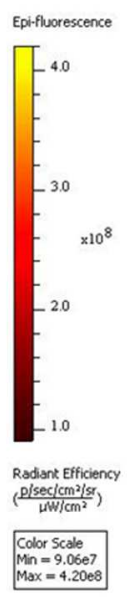

Without background subtraction

Figure S14. Probe 5c for Hela tumor imaging in vivo and ex vivo. (A) Time-dependent in vivo fluorescence images of subcutaneous Hela tumor-bearing mice after intravenous injection of 0.5 $\mathrm{mg} / \mathrm{kg}(10 \mu \mathrm{M}, 200 \mu \mathrm{L}) \mathrm{pH}$-activatable probe 5c via the tail vein. (B) NIR fluorescence imaging $8 \mathrm{~h}$ post i.v. administration of $\mathbf{5 c}$ without intensity scale adjusted. (C) At $8 \mathrm{~h}$ post-injection, mice were sacrificed and organs were collected and imaged using an IVIS Lumina imaging system. 


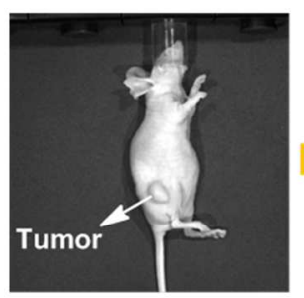

HCC 4017 tumor-bearing mouse

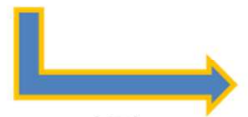

(B)

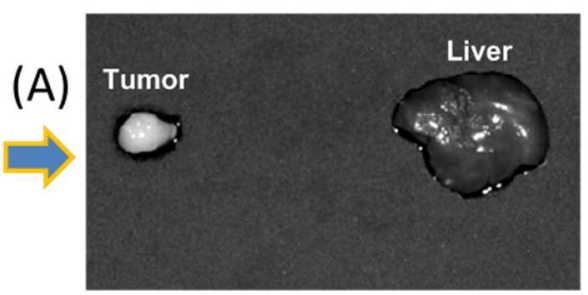

ex vivo image of collected tumor and liver before injection of $5 c$

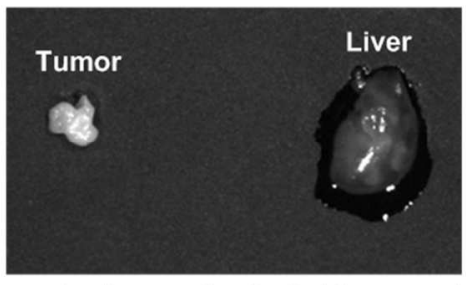

ex vivo image of collected tumor and liver before injection of $\mathbf{5 a}$

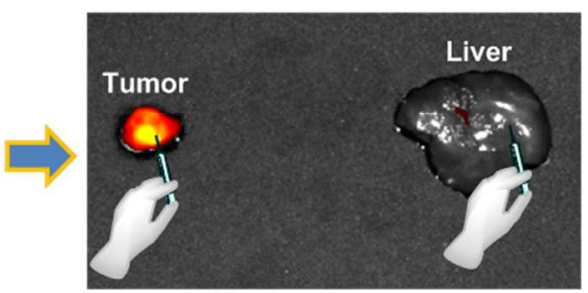

ex vivo image of collected tumor and liver after injection of $5 \mathrm{c}$

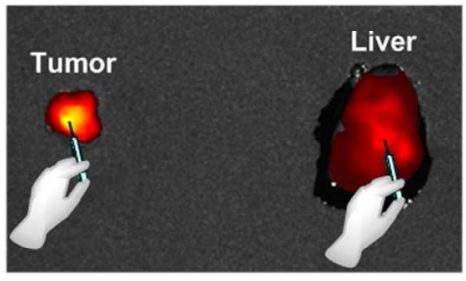

ex vivo image of collected tumor and liver after injection of $\mathbf{5 a}$

Figure S15. Illustration of microenvironment in tumor and liver. (A) The tumor and liver were harvested from a HCC4017 tumor-bearing mouse. Ex vivo imaging of collected tumor and liver was performed 10 min after direct injection of 5c $(1 \mu \mathrm{M}, 100 \mu \mathrm{L})$. (B) Ex vivo image of collected tumor and liver was performed after injection of $\mathbf{5 a}(1 \mu \mathrm{M}, 100 \mu \mathrm{L})$ at 10 min post-injection.

\section{Synthesis of NIR probes}

3.1 General procedure for the synthesis of BODIPYs 1a-e. ${ }^{[5,6]}$

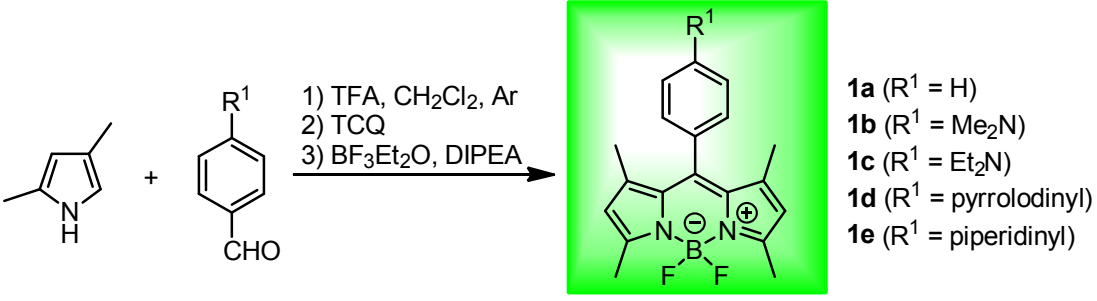

2,4-dimethylpyrrole $(1.0 \mathrm{~mL}, 10.0 \mathrm{mmol})$ and the appropriate $N, N$-dialkylaminobenzaldehyde or benzaldehyde $(5.0 \mathrm{mmol})$ were dissolved in $600 \mathrm{~mL}$ of anhydrous dichloromethane (DCM) containing a catalytic amount of trifluoroacetic acid (TFA). The resulting reddish solution was stirred overnight at ambient temperature under an Ar atmosphere. Tetrachloro-1,4-benzoquinone ( $p$-chloranil) (1.23 g, $5.0 \mathrm{mmol})$ was added and the mixture was stirred for $1 \mathrm{~h}$. Then the DCM was removed under reduced pressure. The residue thus obtained was dissolved in $300 \mathrm{~mL}$ of dry toluene containing $N, N$-diisopropylethylamine (DIPEA) $(6 \mathrm{~mL})$, and the resulting solution was stirred at ambient temperature. $\mathrm{BF}_{3} \cdot \mathrm{OEt}_{2}(6 \mathrm{~mL})$ was then slowly added, and stirring was continued for $2 \mathrm{~h}$. The reaction mixture was washed with brine, dried over anhydrous sodium sulfate, filtered, and concentrated. The crude product was purified by flash column 
chromatography over silica gel using DCM/hexanes as the eluent. Then the collected product was recrystallized in $\mathrm{CH}_{2} \mathrm{Cl}_{2}$ /hexanes (10/90), affording 1a-e as brown-red solid.

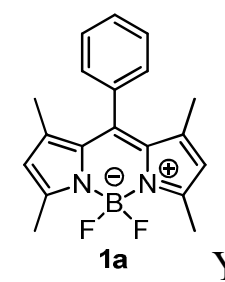

Yield $=16 \% ;{ }^{1} \mathrm{H}$ NMR $\left(400 \mathrm{MHz}, \mathrm{CDCl}_{3}\right): \delta$ 7.51-7.48 (m, 3H), 7.29-7.26 (m, 2H), $5.98(\mathrm{~s}, 2 \mathrm{H}), 2.56(\mathrm{~s}, 6 \mathrm{H}), 1.37(\mathrm{~s}, 6 \mathrm{H})$.

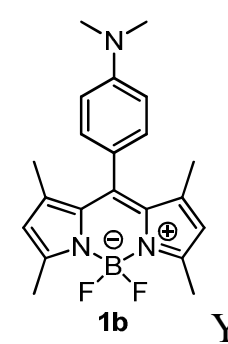

Yield $=45 \% ;{ }^{1} \mathrm{H}$ NMR $\left(500 \mathrm{MHz}, \mathrm{CDCl}_{3}\right): \delta 7.05(\mathrm{~d}, J=8.5 \mathrm{~Hz}, 2 \mathrm{H}), 6.78(\mathrm{~d}, J=$ $8.0 \mathrm{~Hz}, 2 \mathrm{H}), 5.97$ (s, 2H), $3.02(\mathrm{~s}, 6 \mathrm{H}), 2.55$ (s, 6H), 1.48 (s, 6H).

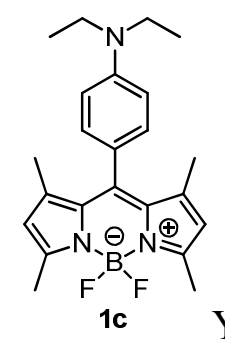

Yield $=27 \% ;{ }^{1} \mathrm{H}$ NMR $\left(400 \mathrm{MHz}, \mathrm{CDCl}_{3}\right): \delta 7.01(\mathrm{~d}, J=8.4 \mathrm{~Hz}, 2 \mathrm{H}), 6.73(\mathrm{~d}, J=$ $8.4 \mathrm{~Hz}, 2 \mathrm{H}), 5.95$ (s, 2H), 3.40 (q, $J=7.2 \mathrm{~Hz}, 4 \mathrm{H}), 2.54$ (s, 6H), 1.51 (s, 6H), 1.19 (t, $J=7.2 \mathrm{~Hz}$, $6 \mathrm{H})$.

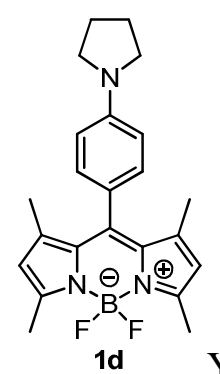

$8.8 \mathrm{~Hz}, 2 \mathrm{H}), 5.96(\mathrm{~s}, 2 \mathrm{H}), 3.33(\mathrm{t}, J=6.4 \mathrm{~Hz}, 4 \mathrm{H}), 2.55(\mathrm{~s}, 6 \mathrm{H}), 2.07-2.04(\mathrm{~m}, 4 \mathrm{H}), 1.51(\mathrm{~s}, 6 \mathrm{H})$. ${ }^{13} \mathrm{C}$ NMR (100 MHz, $\left.\mathrm{CDCl}_{3}\right): \delta 154.55,148.10,143.56,143.25,132.27,128.77,121.14,120.74$, 111.79, 47.53, 25.43, 14.79, 14.54. LRMS-ESI $(\mathrm{m} / \mathrm{z})$ : Exact mass calcd for $\mathrm{C}_{23} \mathrm{H}_{27} \mathrm{BF}_{2} \mathrm{~N}_{3}{ }^{+}$ $[\mathrm{M}+\mathrm{H}]^{+}:$394.2; Found: 394.2 . 


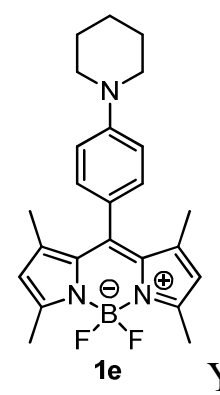

Yield $=30 \% ;{ }^{1} \mathrm{H}$ NMR $\left(400 \mathrm{MHz}, \mathrm{CDCl}_{3}\right): \delta 7.08(\mathrm{~d}, J=8.8 \mathrm{~Hz}, 2 \mathrm{H}), 7.00(\mathrm{~d}, J=$ $8.0 \mathrm{~Hz}, 2 \mathrm{H}), 5.96(\mathrm{~s}, 2 \mathrm{H}), 3.23(\mathrm{t}, J=5.3 \mathrm{~Hz}, 4 \mathrm{H}), 2.54(\mathrm{~s}, 6 \mathrm{H}), 1.74-1.73(\mathrm{~m}, 4 \mathrm{H}), 1.64-1.58(\mathrm{~m}$, $2 \mathrm{H}), 1.46(\mathrm{~s}, 6 \mathrm{H})$.

3.2 Synthesis of NIR BODIPY $2 \mathbf{b}$.
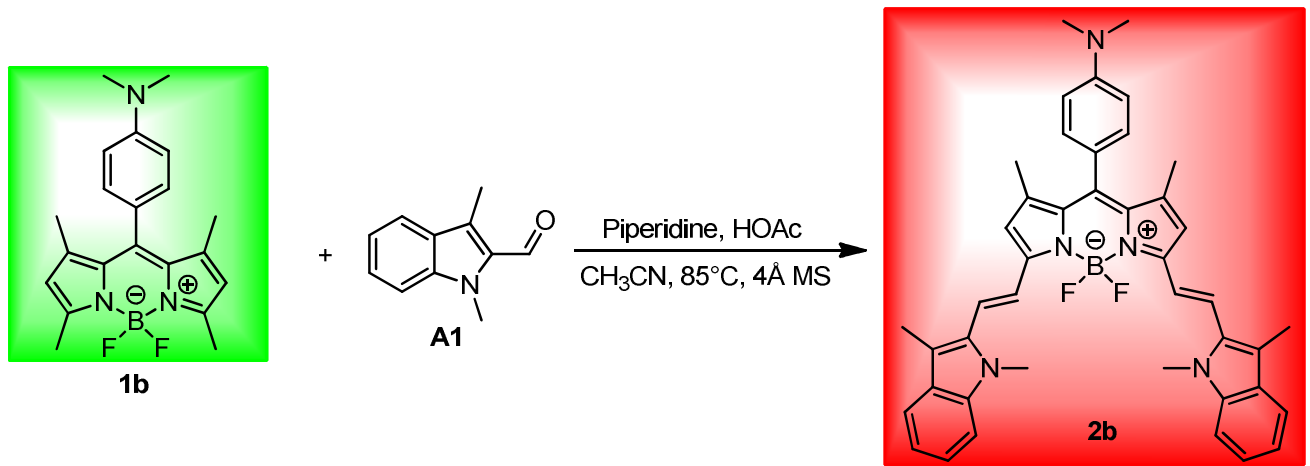

BODIPY 1b (184 mg, $0.5 \mathrm{mmol})$ and 1,3-dimethyl-1H-indole-2-carbaldehyde (520 mg, 3.0 mmol) were refluxed in a mixture of dry acetonitrile $(20 \mathrm{~mL})$, piperidine $(1.0 \mathrm{~mL})$, glacial acetic acid $(0.6 \mathrm{~mL})$, and $4 \AA$ molecular sieves ( $\sim 50$ pellets) under an Ar atmosphere. The reaction mixture was stirred at $85^{\circ} \mathrm{C}$ for $8 \mathrm{~h}$. Then the solvent was removed under reduced pressure. The crude product was purified by flash column chromatography over silica gel using ethyl acetate/hexanes as the eluent. The collected product was then recrystallized in $\mathrm{CH}_{2} \mathrm{Cl}_{2} /$ hexanes (10/90), affording $\mathbf{2 b}$ as gold-brown solid.

Yield $=65 \% ;{ }^{1} \mathrm{H}$ NMR $\left(400 \mathrm{MHz}, \mathrm{CDCl}_{3}\right): \delta 7.68(\mathrm{~d}, J=16.8 \mathrm{~Hz}, 2 \mathrm{H}), 7.60(\mathrm{~d}, J=8.0 \mathrm{~Hz}, 2 \mathrm{H})$, $7.36(\mathrm{~d}, J=16.4 \mathrm{~Hz}, 2 \mathrm{H}), 7.30-7.24(\mathrm{~m}, 4 \mathrm{H}), 7.14-7.10(\mathrm{~m}, 4 \mathrm{H}), 6.81(\mathrm{~d}, J=8.4 \mathrm{~Hz}, 2 \mathrm{H}), 6.68(\mathrm{~s}$, $2 \mathrm{H}), 3.88(\mathrm{~s}, 6 \mathrm{H}), 3.04(\mathrm{~s}, 6 \mathrm{H}), 2.56(\mathrm{~s}, 6 \mathrm{H}), 1.59(\mathrm{~s}, 6 \mathrm{H}) .{ }^{13} \mathrm{C} \mathrm{NMR}\left(100 \mathrm{MHz}, \mathrm{CD}_{2} \mathrm{Cl}_{2}\right): \delta 152.2$, $151.4,143.0,140.3,139.2,134.9,134.5,129.8,129.1,124.0,123.8,122.5,121.3,119.8,119.7$, 117.3, 114.6, 112.8, 109.7, 40.7, 31.4, 15.3, 10.8. LRMS-ESI $(\mathrm{m} / \mathrm{z})$ : Exact mass calcd for $\mathrm{C}_{43} \mathrm{H}_{43} \mathrm{BF}_{2} \mathrm{~N}_{5}^{+}[\mathrm{M}+\mathrm{H}]^{+}:$678.4; Found: 678.2.

\subsection{Synthesis of NIR BODIPY 3b.}



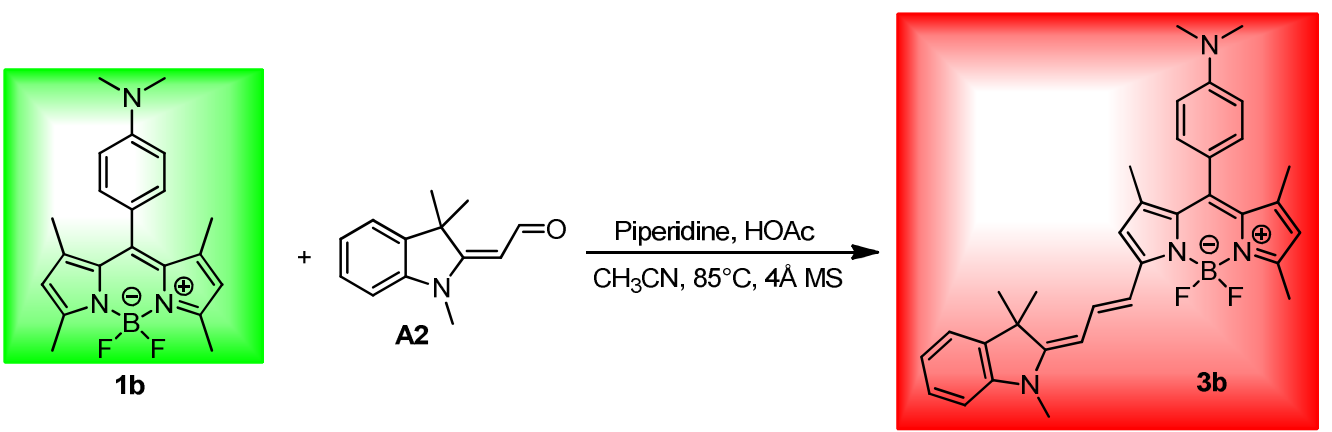

BODIPY $1 \mathbf{b}(184 \mathrm{mg}, 0.5 \mathrm{mmol})$ and the Fisher aldehyde $(131 \mathrm{mg}, 1.3 \mathrm{mmol})$ were refluxed in a mixture of dry acetonitrile $(20 \mathrm{~mL})$, piperidine $(1.0 \mathrm{~mL})$, glacial acetic acid $(0.6 \mathrm{~mL})$, and 4 $\AA$ molecular sieves ( $\sim 50$ pellets) under an Ar atmosphere. The reaction mixture was stirred at $85{ }^{\circ} \mathrm{C}$ for $2 \mathrm{~h}$. Then the solvent was removed under reduced pressure. The crude product was purified by flash column chromatography over silica gel using ethyl acetate/hexanes as the eluent. The collected product was then recrystallized in $\mathrm{CH}_{2} \mathrm{Cl}_{2} / \mathrm{Hexanes}$ (10/90), affording $\mathbf{3 b}$ as brown-green solid.

Yield $=50 \% ;{ }^{1} \mathrm{H}$ NMR $\left(500 \mathrm{MHz}, \mathrm{CDCl}_{3}\right): \delta 7.55(\mathrm{t}, J=13.5 \mathrm{~Hz}, 1 \mathrm{H}), 7.20(\mathrm{t}, J=7.5 \mathrm{~Hz}, 1 \mathrm{H})$, $7.16(\mathrm{~d}, J=7.0 \mathrm{~Hz}, 1 \mathrm{H}), 7.10-7.09(\mathrm{~m}, 2 \mathrm{H}), 6.91-6.78(\mathrm{~m}, 4 \mathrm{H}), 6.69(\mathrm{~d}, J=7.5 \mathrm{~Hz}, 1 \mathrm{H}), 6.49(\mathrm{~s}$, $1 \mathrm{H}), 5.91(\mathrm{~s}, 1 \mathrm{H}), 5.66(\mathrm{~d}, J=11.5 \mathrm{~Hz}, 1 \mathrm{H}), 3.18(\mathrm{~s}, 3 \mathrm{H}), 3.02(\mathrm{~s}, 6 \mathrm{H}), 2.55(\mathrm{~s}, 3 \mathrm{H}), 1.60(\mathrm{~s}, 6 \mathrm{H})$, $1.52(\mathrm{~s}, 3 \mathrm{H}), 1.46(\mathrm{~s}, 3 \mathrm{H}) .{ }^{13} \mathrm{C} \mathrm{NMR}\left(100 \mathrm{MHz}, \mathrm{CDCl}_{3}\right): \delta 160.6,155.4,150.4,149.9,144.6$, 143.2, 139.1, 138.7, 138.1, 135.2, 134.2, 131.4, 129.3, 127.8, 123.0, 121.6, 120.4, 119.2, 117.4, 114.2, 112.2, 106.6, 98.4, 46.1, 40.4, 30.9, 29.2, 28.7, 15.0, 14.4. LRMS-ESI $(\mathrm{m} / \mathrm{z})$ : Exact mass calcd for $\mathrm{C}_{34} \mathrm{H}_{38} \mathrm{BF}_{2} \mathrm{~N}_{4}^{+}[\mathrm{M}+\mathrm{H}]^{+}$: 551.3; Found: 551.2.

3.4 General experimental procedure for synthesis of 5a-e.
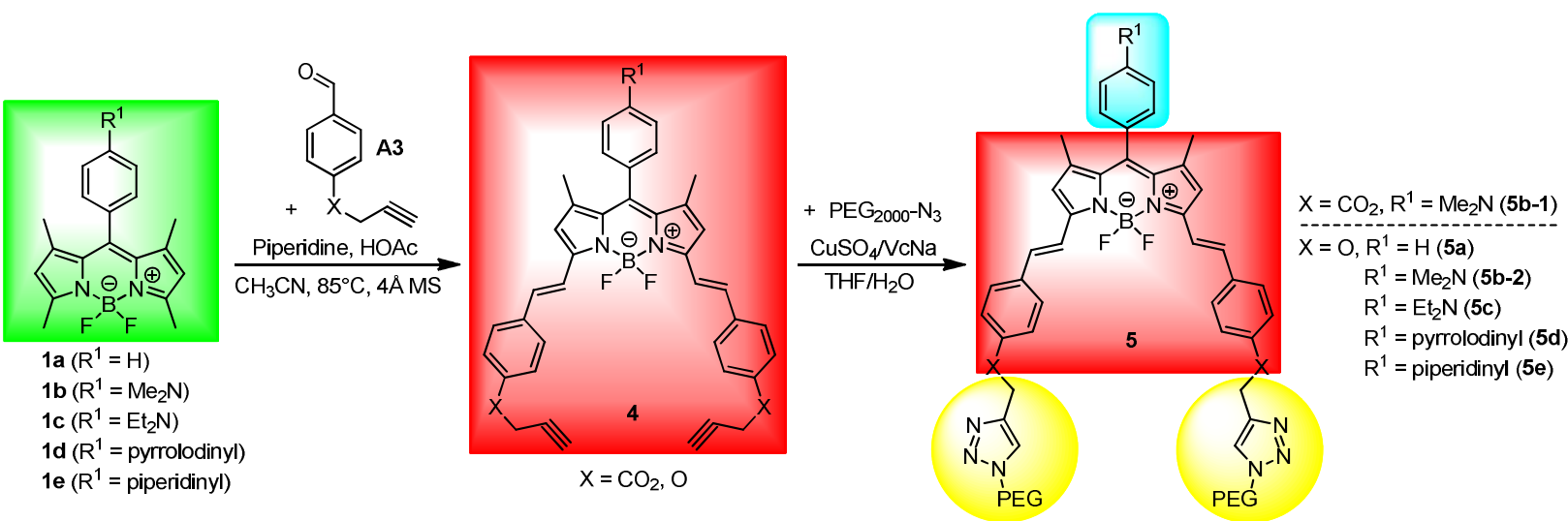

BODIPY $1(0.5 \mathrm{mmol})$ and the appropriate propargyl benzaldehyde $\mathbf{A 3}(3.0 \mathrm{mmol})$ were refluxed in a mixture of dry acetonitrile $(20 \mathrm{~mL})$, piperidine $(1.0 \mathrm{~mL})$, glacial acetic acid $(0.6$ $\mathrm{mL})$, and $4 \AA$ molecular sieves ( $\sim 50$ pellets) under an Ar atmosphere. The reaction mixture was 
stirred at $85{ }^{\circ} \mathrm{C}$ for $8 \mathrm{~h}$. Then the solvent was removed under reduced pressure. The crude product was first purified by flash column chromatography over silica gel using ethyl acetate/hexanes as the eluent to remove the excess A3. Subsequently, the eluent was changed to $\mathrm{DCM} /$ hexanes to obtain the desired product. The collected product was then recrystallized in $\mathrm{CH}_{2} \mathrm{Cl}_{2} /$ hexanes (10/90), yielding 4 as gold-brown or dark-blue solid.

NIR BODIPY $4(0.04 \mathrm{mmol})$, methoxy-poly(ethylene glycol)-azide (PEG-N ${ }_{3}$, average $M_{\mathrm{n}}=$ 2000, $192 \mathrm{mg}, 0.096 \mathrm{mmol}), \mathrm{CuSO}_{4}(1.3 \mathrm{mg}, 0.008 \mathrm{mmol}$ ), and sodium ascorbate (VcNa, 15.8 $\mathrm{mg}, 0.08 \mathrm{mmol}$ ) were added to a $10 \mathrm{~mL}$ schlenk flask. The vessel was evacuated and back-filled with Ar. Then the flask was cooled to $0{ }^{\circ} \mathrm{C}$ for 20 minutes and $4 \mathrm{~mL}$ THF (degassed) was added via a syringe, followed by $1 \mathrm{~mL}$ DI water (degassed). The reaction mixture was slowly warmed to room temperature and stirred overnight. After evaporation of THF, the residue was dialyzed in DI water for $6 \mathrm{~h}$ and lyophilized to obtain a blue powder. The collected product was then purified by column chromatography through a Sephadex LH-20 resin using $\mathrm{MeOH}$ as the eluent, affording 5a-e as blue solid.

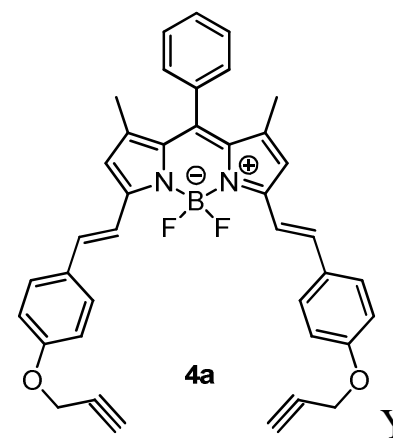

Yield $=49 \% ;{ }^{1} \mathrm{H}$ NMR $\left(400 \mathrm{MHz}, \mathrm{CDCl}_{3}\right): \delta 7.65-7.59(\mathrm{~m}, 6 \mathrm{H}), 7.51-7.49$ (m, 3H), 7.34-7.32 (m, 2H), $7.21(\mathrm{~d}, J=16.0 \mathrm{~Hz}, 2 \mathrm{H}), 7.01(\mathrm{~d}, J=8.8 \mathrm{~Hz}, 2 \mathrm{H}), 6.62(\mathrm{~s}, 2 \mathrm{H})$, $4.74(\mathrm{~d}, J=2.4 \mathrm{~Hz}, 4 \mathrm{H}), 2.56(\mathrm{t}, J=2.4 \mathrm{~Hz}, 2 \mathrm{H}), 1.44(\mathrm{~s}, 6 \mathrm{H}) .{ }^{13} \mathrm{C} \mathrm{NMR}\left(100 \mathrm{MHz}, \mathrm{CDCl}_{3}\right): \delta$ 158.2, 152.6, 141.9, 138.4, 135.5, 135.2, 133.2, 130.4, 129.03, 128.95, 128.9, 128.5, 117.7, 117.5, 115.2, 78.2, 75.8, 55.8, 14.6. LRMS-ESI $(m / z)$ : Exact mass calcd for $\mathrm{C}_{39} \mathrm{H}_{32} \mathrm{BF}_{2} \mathrm{~N}_{2} \mathrm{O}_{2}{ }^{+}[\mathrm{M}+\mathrm{H}]^{+}$: 609.3; Found: 609.4.

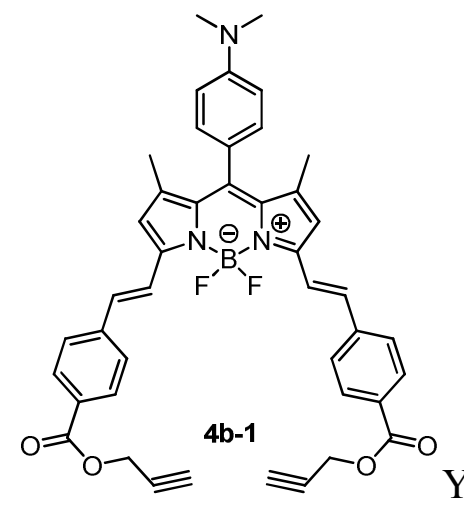

Yield $=18 \% ;{ }^{1} \mathrm{H}$ NMR $\left(400 \mathrm{MHz}, \mathrm{CDCl}_{3}\right): \delta 8.09(\mathrm{~d}, J=8.4 \mathrm{~Hz}, 4 \mathrm{H})$, $7.84(\mathrm{~d}, J=16.0 \mathrm{~Hz}, 2 \mathrm{H}), 7.69$ (d, $J=8.4 \mathrm{~Hz}, 4 \mathrm{H}), 7.25(\mathrm{~d}, J=16.0 \mathrm{~Hz}, 2 \mathrm{H}), 7.11$ (d, $J=8.8 \mathrm{~Hz}$, $2 \mathrm{H}), 6.80(\mathrm{~d}, J=8.8 \mathrm{~Hz}, 2 \mathrm{H}), 6.68(\mathrm{~s}, 2 \mathrm{H}), 4.95(\mathrm{~d}, J=2.4 \mathrm{~Hz}, 4 \mathrm{H}), 3.04(\mathrm{~s}, 6 \mathrm{H}), 2.54(\mathrm{t}, J=2.4$ 
$\mathrm{Hz}, 2 \mathrm{H}), 1.58(\mathrm{~s}, 6 \mathrm{H}) .{ }^{13} \mathrm{C}$ NMR $\left(100 \mathrm{MHz}, \mathrm{CDCl}_{3}\right): \delta 165.4,151.6,150.8,143.0,141.8,141.4$, 134.7, 134.3, 130.3, 129.0, 127.3, 121.82, 121.79, 118.0, 112.3, 77.7, 75.0, 52.5, 40.3, 15.0. LRMS-ESI $(m / z)$ : Exact mass calcd for $\mathrm{C}_{43} \mathrm{H}_{37} \mathrm{BF}_{2} \mathrm{~N}_{3} \mathrm{O}_{4}{ }^{+}[\mathrm{M}+\mathrm{H}]^{+}$: 708.3; Found: 708.2.

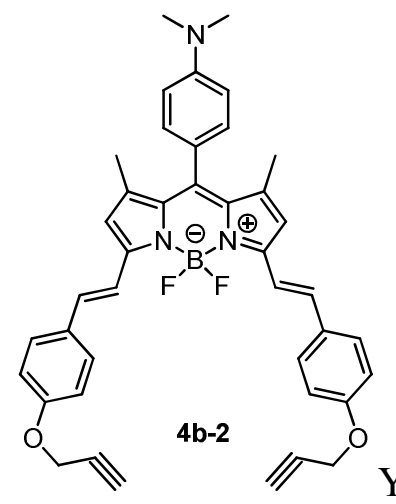

$=16.0 \mathrm{~Hz}, 2 \mathrm{H}), 7.10(\mathrm{~d}, J=8.0 \mathrm{~Hz}, 2 \mathrm{H}), 7.01(\mathrm{~d}, J=8.4 \mathrm{~Hz}, 4 \mathrm{H}), 6.79(\mathrm{~d}, J=8.4 \mathrm{~Hz}, 2 \mathrm{H}), 6.61$ (s, $2 \mathrm{H}), 4.74(\mathrm{~d}, J=2.0 \mathrm{~Hz}, 4 \mathrm{H}), 3.03(\mathrm{~s}, 6 \mathrm{H}), 2.55(\mathrm{t}, J=2.4 \mathrm{~Hz}, 2 \mathrm{H}), 1.55(\mathrm{~s}, 6 \mathrm{H}) .{ }^{13} \mathrm{C}$ NMR (100 MHz, $\left.\mathrm{CDCl}_{3}\right): \delta 158.1,152.1,150.6,142.1,140.0,134.9,134.0,130.5,129.2,128.9,122.4$, 117.9, 117.2, 115.2, 112.2, 78.3, 75.8, 55.8, 40.3, 14.9. LRMS-ESI $(\mathrm{m} / \mathrm{z})$ : Exact mass calcd for $\mathrm{C}_{41} \mathrm{H}_{37} \mathrm{BF}_{2} \mathrm{~N}_{3} \mathrm{O}_{2}{ }^{+}[\mathrm{M}+\mathrm{H}]^{+}: 652.3$; Found: 652.2 .

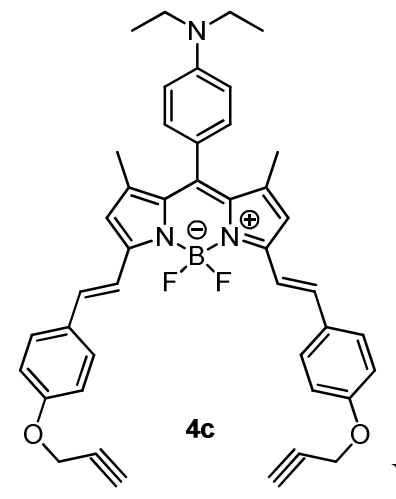

Yield $=60 \% ;{ }^{1} \mathrm{H}$ NMR $\left(400 \mathrm{MHz}, \mathrm{CDCl}_{3}\right): \delta 7.65-7.58(\mathrm{~m}, 6 \mathrm{H}), 7.19(\mathrm{~d}, J$ $=16.4 \mathrm{~Hz}, 2 \mathrm{H}), 7.06(\mathrm{~d}, J=8.4 \mathrm{~Hz}, 2 \mathrm{H}), 7.01(\mathrm{~d}, J=8.4 \mathrm{~Hz}, 4 \mathrm{H}), 6.75(\mathrm{~d}, J=8.8 \mathrm{~Hz}, 2 \mathrm{H}), 6.61$ (s, 2H), 4.74 (d, $J=2.4 \mathrm{~Hz}, 4 \mathrm{H}), 3.41$ (q, $J=7.2 \mathrm{~Hz}, 4 \mathrm{H}), 2.55$ (t, $J=2.4 \mathrm{~Hz}, 2 \mathrm{H}), 1.58(\mathrm{~s}, 6 \mathrm{H})$, $1.21(\mathrm{t}, J=7.2 \mathrm{~Hz}, 6 \mathrm{H}) .{ }^{13} \mathrm{C} \mathrm{NMR}\left(100 \mathrm{MHz}, \mathrm{CDCl}_{3}\right): \delta 158.0,152.0,148.1,142.1,140.3,134.8$, 134.0, 130.5, 129.3, 128.8, 121.4, 117.9, 117.2, 115.1, 111.9, 78.3, 75.8, 55.8, 44.3, 15.0, 12.4 . LRMS-ESI $(m / z)$ : Exact mass calcd for $\mathrm{C}_{43} \mathrm{H}_{41} \mathrm{BF}_{2} \mathrm{~N}_{3} \mathrm{O}_{2}{ }^{+}[\mathrm{M}+\mathrm{H}]^{+}$: 680.3; Found: 680.2. 


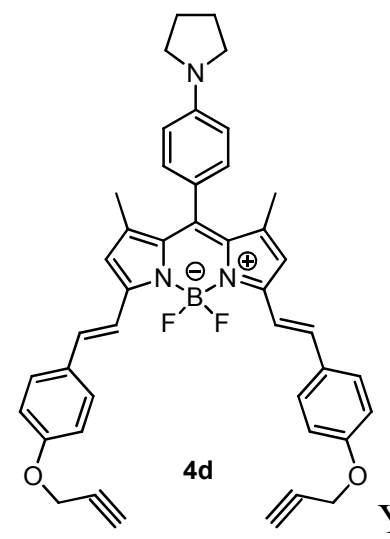

$=16.0 \mathrm{~Hz}, 2 \mathrm{H}), 7.11(\mathrm{~d}, J=8.0 \mathrm{~Hz}, 2 \mathrm{H}), 7.01(\mathrm{~d}, J=8.4 \mathrm{~Hz}, 4 \mathrm{H}), 6.73(\mathrm{~d}, J=5.6 \mathrm{~Hz}, 2 \mathrm{H}), 6.61$ $(\mathrm{s}, 2 \mathrm{H}), 4.74(\mathrm{~d}, J=2.4 \mathrm{~Hz}, 4 \mathrm{H}), 3.38(\mathrm{~m}, 4 \mathrm{H}), 2.55(\mathrm{t}, J=2.0 \mathrm{~Hz}, 2 \mathrm{H}), 2.09(\mathrm{~m}, 4 \mathrm{H}), 1.56(\mathrm{~s}$, $6 \mathrm{H}) .{ }^{13} \mathrm{C}$ NMR $\left(100 \mathrm{MHz}, \mathrm{CDCl}_{3}\right): \delta 158.0,152.0,148.1,142.2,140.4,134.8,134.1,130.5$, 129.2, 128.8, 121.4, 118.0, 117.1, 115.1, 111.7, 78.3, 75.8, 55.8, 47.6, 25.4, 15.0. LRMS-ESI $(\mathrm{m} / \mathrm{z})$ : Exact mass calcd for $\mathrm{C}_{43} \mathrm{H}_{39} \mathrm{BF}_{2} \mathrm{~N}_{3} \mathrm{O}_{2}^{+}[\mathrm{M}+\mathrm{H}]^{+}$: 678.3; Found: 678.2 .

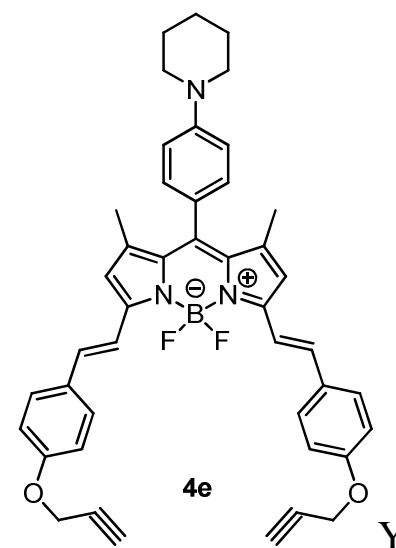$$
=16.0 \mathrm{~Hz}, 2 \mathrm{H}), 7.13(\mathrm{~d}, J=8.8 \mathrm{~Hz}, 2 \mathrm{H}), 7.03-7.00
$$

$=16.0 \mathrm{~Hz}, 2 \mathrm{H}), 7.13(\mathrm{~d}, J=8.8 \mathrm{~Hz}, 2 \mathrm{H}), 7.03-7.00(\mathrm{~m}, 6 \mathrm{H}), 6.61(\mathrm{~s}, 2 \mathrm{H}), 4.74(\mathrm{~d}, J=2.4 \mathrm{~Hz}$, $4 \mathrm{H}), 3.24(\mathrm{t}, J=5.6 \mathrm{~Hz}, 4 \mathrm{H}), 2.55(\mathrm{t}, J=2.4 \mathrm{~Hz}, 2 \mathrm{H}), 1.78-1.72(\mathrm{~m}, 4 \mathrm{H}), 1.65-1.61(\mathrm{~m}, 2 \mathrm{H}), 1.53$ (s, 6H). ${ }^{13} \mathrm{C}$ NMR $\left(100 \mathrm{MHz}, \mathrm{CDCl}_{3}\right): \delta 158.1,152.4,152.2,142.1,139.4,135.1,133.8,130.5$, $129.1,128.9,125.0,117.9,117.3,116.2,115.2,78.3,75.8,55.8,50.1,25.6,24.2,14.9$. LRMSESI $(m / z)$ : Exact mass calcd for $\mathrm{C}_{44} \mathrm{H}_{41} \mathrm{BF}_{2} \mathrm{~N}_{3} \mathrm{O}_{2}{ }^{+}[\mathrm{M}+\mathrm{H}]^{+}$: 692.3; Found: 692.2. 


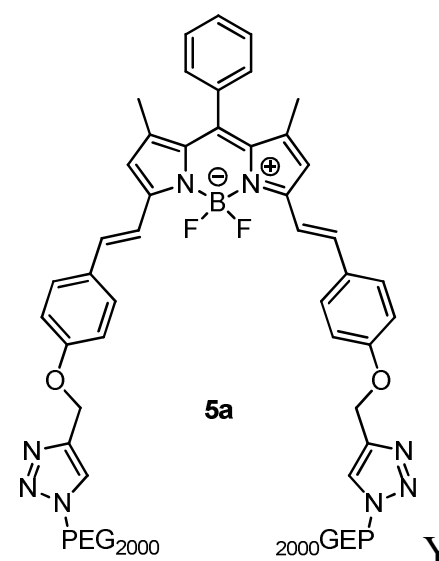

$(\mathrm{m}, 9 \mathrm{H}), 7.43-7.39(\mathrm{~m}, 4 \mathrm{H}), 7.12(\mathrm{~d}, J=8.4 \mathrm{~Hz}, 4 \mathrm{H}), 6.83(\mathrm{~s}, 2 \mathrm{H}), 5.27(\mathrm{~s}, 4 \mathrm{H}), 4.62(\mathrm{t}, J=4.8$ $\mathrm{Hz}, 4 \mathrm{H}), 3.90(\mathrm{t}, J=4.8 \mathrm{~Hz}, 4 \mathrm{H}), 3.64-3.57$ (m, 344H), 3.35 (s, 6H), 1.48 (s, 6H).

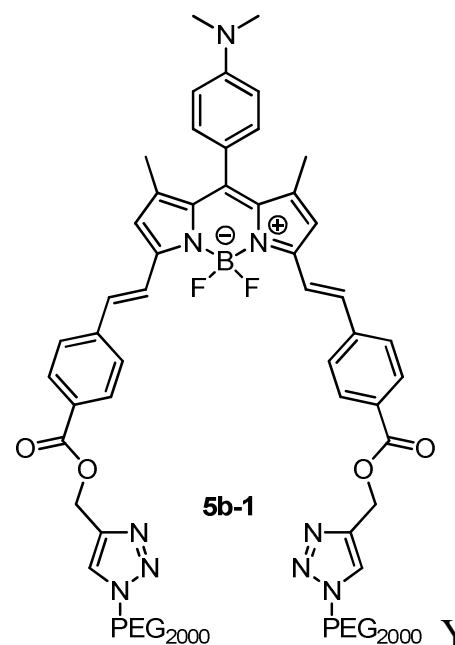

$=8.4 \mathrm{~Hz}, 4 \mathrm{H}), 7.82-7.75(\mathrm{~m}, 6 \mathrm{H}), 7.50(\mathrm{~d}, J=16.4 \mathrm{~Hz}, 2 \mathrm{H}), 7.15(\mathrm{~d}, J=8.8 \mathrm{~Hz}, 2 \mathrm{H}), 6.93(\mathrm{~d}, J=$ $8.8 \mathrm{~Hz}, 2 \mathrm{H}), 6.90(\mathrm{~s}, 2 \mathrm{H}), 5.48(\mathrm{~s}, 4 \mathrm{H}), 4.64(\mathrm{t}, J=4.8 \mathrm{~Hz}, 4 \mathrm{H}), 3.92$ (t, $J=4.8 \mathrm{~Hz}, 4 \mathrm{H}), 3.63-$ $3.57(\mathrm{~m}, 344 \mathrm{H}), 3.35(\mathrm{~s}, 6 \mathrm{H}), 3.04(\mathrm{~s}, 6 \mathrm{H}), 1.62(\mathrm{~s}, 6 \mathrm{H})$. 


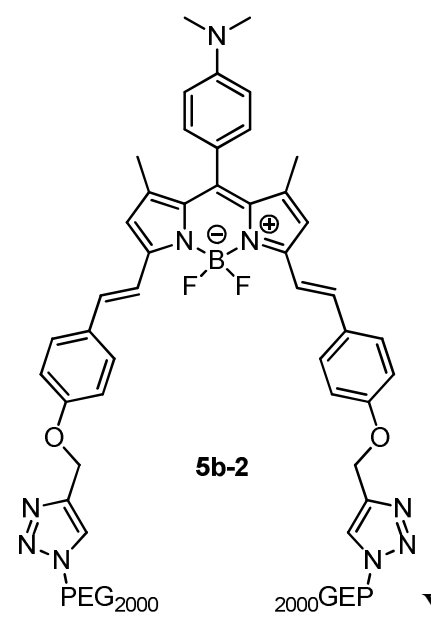

$(\mathrm{m}, 6 \mathrm{H}), 7.38(\mathrm{~d}, J=16.4 \mathrm{~Hz}, 2 \mathrm{H}), 7.14-7.10(\mathrm{~m}, 6 \mathrm{H}), 6.91(\mathrm{~d}, J=8.8 \mathrm{~Hz}, 2 \mathrm{H}), 6.80(\mathrm{~s}, 2 \mathrm{H})$ $5.26(\mathrm{~s}, 4 \mathrm{H}), 4.61(\mathrm{t}, J=4.8 \mathrm{~Hz}, 4 \mathrm{H}), 3.90(\mathrm{t}, J=4.8 \mathrm{~Hz}, 4 \mathrm{H}), 3.63-3.57(\mathrm{~m}, 344 \mathrm{H}), 3.35(\mathrm{~s}, 6 \mathrm{H})$, $3.04(\mathrm{~s}, 6 \mathrm{H}), 1.59(\mathrm{~s}, 6 \mathrm{H})$.

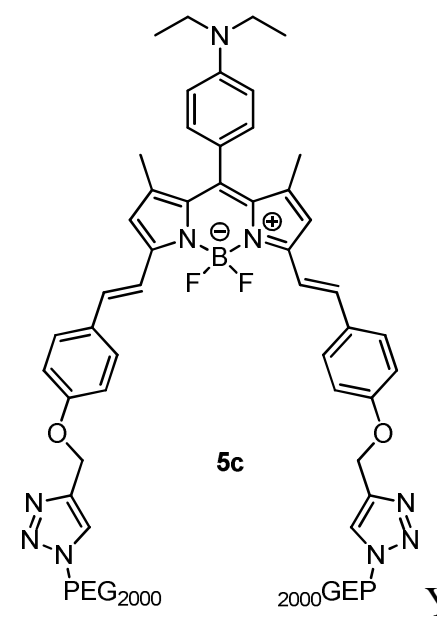

$8.4 \mathrm{~Hz}, 4 \mathrm{H}), 7.57(\mathrm{~d}, J=17.6 \mathrm{~Hz}, 2 \mathrm{H}), 7.38(\mathrm{~d}, J=16.0 \mathrm{~Hz}, 2 \mathrm{H}), 7.13-7.10(\mathrm{~m}, 6 \mathrm{H}), 6.88(\mathrm{~d}, J=$ $8.8 \mathrm{~Hz}, 2 \mathrm{H}), 6.80(\mathrm{~s}, 2 \mathrm{H}), 5.27(\mathrm{~s}, 4 \mathrm{H}), 4.62(\mathrm{t}, J=4.8 \mathrm{~Hz}, 4 \mathrm{H}), 3.90$ (t, $J=4.8 \mathrm{~Hz}, 4 \mathrm{H}), 3.63-$ $3.57(\mathrm{~m}, 348 \mathrm{H}), 3.35(\mathrm{~s}, 6 \mathrm{H}), 1.63(\mathrm{~s}, 6 \mathrm{H}), 1.21(\mathrm{t}, J=7.2 \mathrm{~Hz}, 6 \mathrm{H})$. 


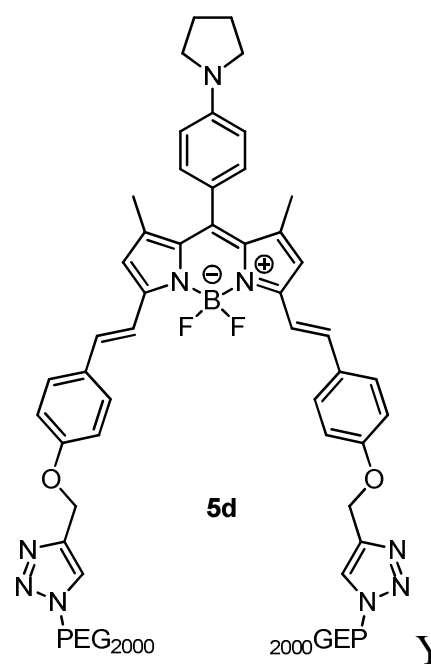

$8.8 \mathrm{~Hz}, 4 \mathrm{H}), 7.56(\mathrm{~d}, J=16.4 \mathrm{~Hz}, 2 \mathrm{H}), 7.38(\mathrm{~d}, J=16.0 \mathrm{~Hz}, 2 \mathrm{H}), 7.12-7.09(\mathrm{~m}, 6 \mathrm{H}), 6.80(\mathrm{~s}, 2 \mathrm{H})$, $6.73(\mathrm{~d}, J=8.4 \mathrm{~Hz}, 2 \mathrm{H}), 5.26(\mathrm{~s}, 4 \mathrm{H}), 4.61(\mathrm{t}, J=4.8 \mathrm{~Hz}, 4 \mathrm{H}), 3.89(\mathrm{t}, J=4.8 \mathrm{~Hz}, 4 \mathrm{H}), 3.64-3.56$ $(\mathrm{m}, 344 \mathrm{H}), 3.35-3.33(\mathrm{~m}, 10 \mathrm{H}), 2.07(\mathrm{~m}, 4 \mathrm{H}), 1.60(\mathrm{~s}, 6 \mathrm{H})$.

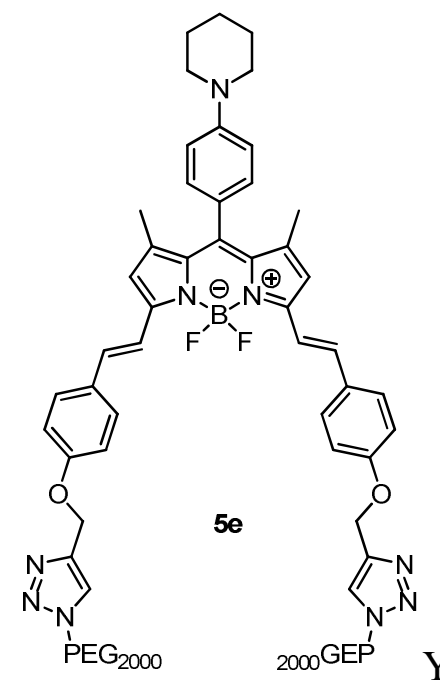

$8.8 \mathrm{~Hz}, 4 \mathrm{H}), 7.56(\mathrm{~d}, J=16.0 \mathrm{~Hz}, 2 \mathrm{H}), 7.39$ (d, $J=16.4 \mathrm{~Hz}, 2 \mathrm{H}), 7.17-7.10(\mathrm{~m}, 8 \mathrm{H}), 6.81(\mathrm{~s}, 2 \mathrm{H})$, $5.27(\mathrm{~s}, 4 \mathrm{H}), 4.61(\mathrm{t}, J=4.8 \mathrm{~Hz}, 4 \mathrm{H}), 3.90(\mathrm{t}, J=4.8 \mathrm{~Hz}, 4 \mathrm{H}), 3.63-3.56(\mathrm{~m}, 344 \mathrm{H}), 3.35(\mathrm{~s}, 6 \mathrm{H})$, $3.30(\mathrm{~m}, 4 \mathrm{H}), 1.75-1.73(\mathrm{~m}, 4 \mathrm{H}), 1.65(\mathrm{~m}, 2 \mathrm{H}), 1.58(\mathrm{~s}, 6 \mathrm{H})$.

\section{Cell culture and confocal microscopy}

All cell lines were cultured in high glucose Dulbecco's Modified Eagle's Medium or RPMI1640 medium containing 5\% fetal bovine serum (FBS). Cells were maintained at $37{ }^{\circ} \mathrm{C}$ under a humidified atmosphere with 5\% $\mathrm{CO}_{2}$. (DMEM for Hela, Huh7, and A549 cell lines. RPMI for MDA-MB-231, SKOV3, and HCC4017 cell lines.) 
Prior to confocal imaging studies, cells were seeded at a density of 10,000 cells per well in 8chambered cover glass slides (Nunc) in $300 \mu \mathrm{L}$ of media and allowed to attach for 24 hours. On the following day, the media was removed and replaced with fresh DMEM or RPMI $(300 \mu \mathrm{L})$. The probe of interest (5a-e) $(5 \mu \mathrm{M})$ was added and the cells were incubated for 30 min or $4 \mathrm{~h}$. Then the cells were washed twice with phosphate buffered saline (PBS) and incubated with the LysoTracker Green DND-26 $(0.5 \mu \mathrm{M}, 200 \mu \mathrm{L})$ for $30 \mathrm{~min}$. The cells were fixed by 4\% PFA (200 $\mu \mathrm{L})$ and stained with DAPI $(0.3 \mu \mathrm{M}, 200 \mu \mathrm{L})$ for $10 \mathrm{~min}$. After labeling, cells were washed twice with PBS and incubated with fresh PBS for fluorescence imaging. Confocal microscopy imaging was performed using a Zeiss LSM 700 Confocal. All imaging settings were held constant across all experiments imaging different probes. The use of identical settings allowed for proper comparison of different dyes. Images were analyzed using ImageJ (NIH).

\section{Cell viability studies}

HeLa cells were seeded in white opaque flat-bottom 96-well plates at a cell density of 10,000 cells per well in $100 \mu \mathrm{L}$ growth medium. After $24 \mathrm{~h}$ to allow cell adhesion, the medium was exchanged for $180 \mu \mathrm{L}$ fresh growth medium. Probes 5a-e were serially diluted in PBS. Probe dilutions $(100 \mu \mathrm{L})$ were added to the cells via multichannel pipette for final micelle concentrations of 2.3 to $154.7 \mu \mathrm{M}$. The cells were then incubated for 24 hours. After this time, cell viability was evaluated by the CellTiter-Glo assay and normalized to a PBS control, $\mathrm{n}=3$.

\section{In vivo imaging and biodistribution of breast, lung, and cervical tumor- bearing mice}

Female athymic nude Foxn $1^{\text {nu }}$ mice were purchased from Harlan Laboratories. All experiments were approved by the Institutional Animal Care and Use Committees of The University of Texas Southwestern Medical Center and were consistent with local, state and federal regulations as applicable. MDA-MB-231, HCC4017, or Hela tumor cells $\left(5 \times 10^{6}\right)$ in 100 $\mu \mathrm{L}$ HBSS/Matrigel (v/v, 50/50) were injected subcutaneously into each flank of 6 weeks old nude mice. After three (for breast and cervical tumor) or five (for lung tumor) weeks, when the tumors reached adequate size, probe 5c $(10 \mu \mathrm{M})$ in $200 \mu \mathrm{L}$ PBS was injected intravenously through the tail vein $(0.5 \mathrm{mg} / \mathrm{kg}$ dose i.v.). In the control groups, the "always on" probe 5a or sulfo-Cy5 or ICG $(10 \mu \mathrm{M}, 200 \mu \mathrm{L})$ was administrated i.v. For the intratumoral injection, $200 \mu \mathrm{L}$ of 5c in PBS $(10 \mu \mathrm{M})$ was directly injected into the tumor. Mice were anesthetized with $2.5 \%$ isofluorane in oxygen at selected time points and the whole body NIR fluorescence images (the Cy5.5 filter was used) were captured using an IVIS Lumina imaging system (Caliper Life Sciences). At the end point ( $6 \mathrm{~h}, 8 \mathrm{~h}$, or $24 \mathrm{~h})$, mice were euthanized and their livers, tumors, lungs, hearts, kidneys, spleens, and muscle were collected. Ex vivo fluorescence imaging of these 
organs was immediately performed on the IVIS Lumina. The fluorescent signal of organs was normalized to the fluorescent signal in the muscle within a representative region of interest (ROI).

\section{Ex vivo analysis of liver and tumor}

Female athymic nude Foxn $1^{\text {nu }}$ mice $(n=3)$ bearing subcutaneous MDA-MB-231 tumors were intravenously injected with $\mathrm{pH}$-activatable probe $5 \mathbf{c}$ at a dose of $0.5 \mathrm{mg} / \mathrm{kg}(10 \mu \mathrm{M}, 200 \mu \mathrm{L}$ in PBS) via the tail vein. The mice were sacrificed at 8 hours post-injection. Liver and tumor were immediately collected and frozen in OCT (Tissue-Tek, Sakura Finetek, Torrance, CA) at $-20{ }^{\circ} \mathrm{C}$ for $20 \mathrm{~min}$. Then the frozen tissues were cut into $10 \mu \mathrm{m}$ sections using Leica CM3050 S cryostat. The sections were fixed in cold acetone $\left(-20^{\circ} \mathrm{C}\right)$ for $10 \mathrm{~min}$, washed with PBS for $5 \mathrm{~min}(3 \times)$, and mounted with medium containing DAPI (Vector Laboratories Inc., CA, USA). Fluorescence images were captured on a Zeiss LSM 700 Confocal and analyzed using ImageJ (NIH). 


\section{8. ${ }^{1} \mathrm{H}$ NMR and ${ }^{13} \mathrm{C}$ NMR spectra of the probes}
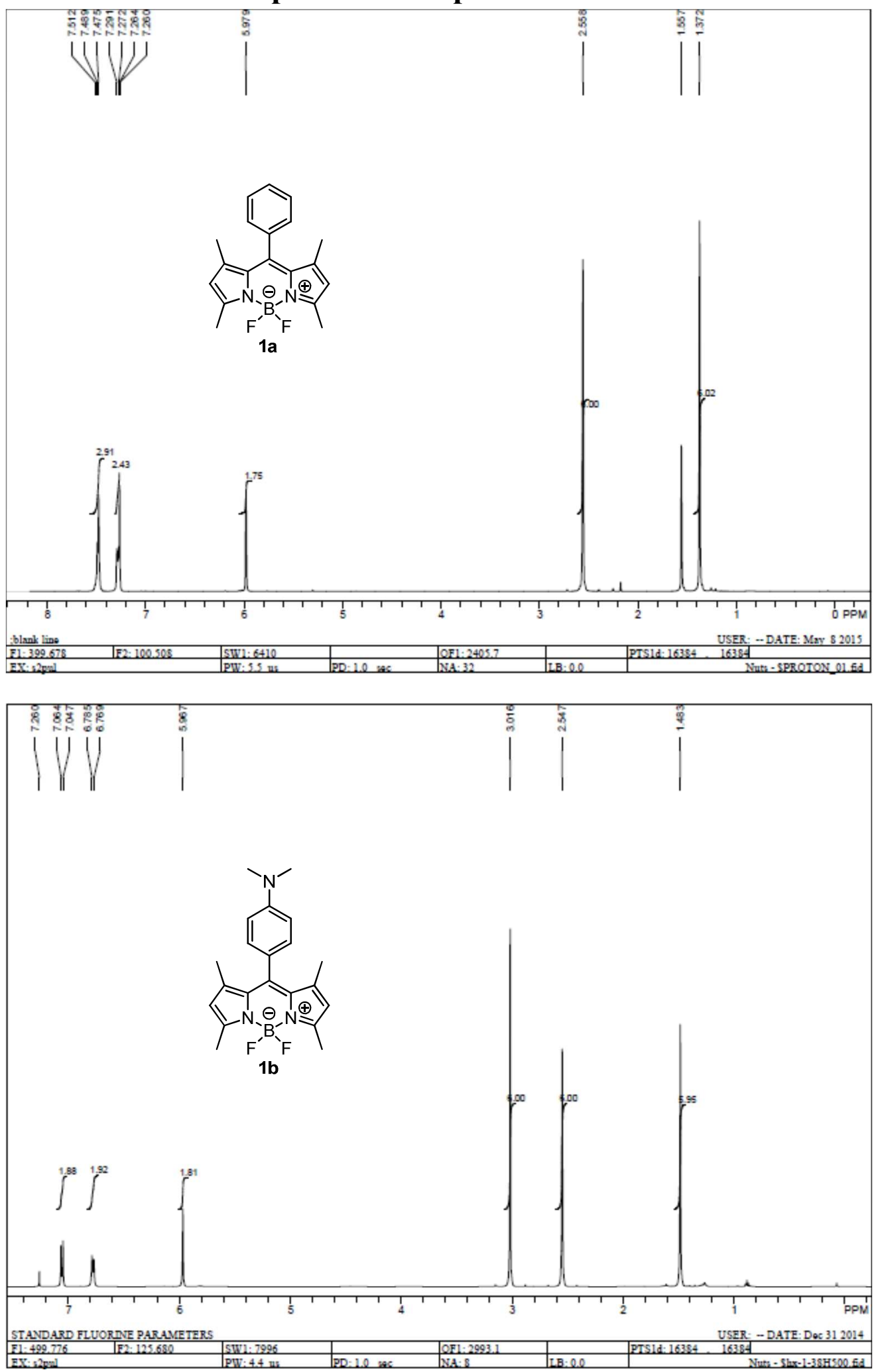

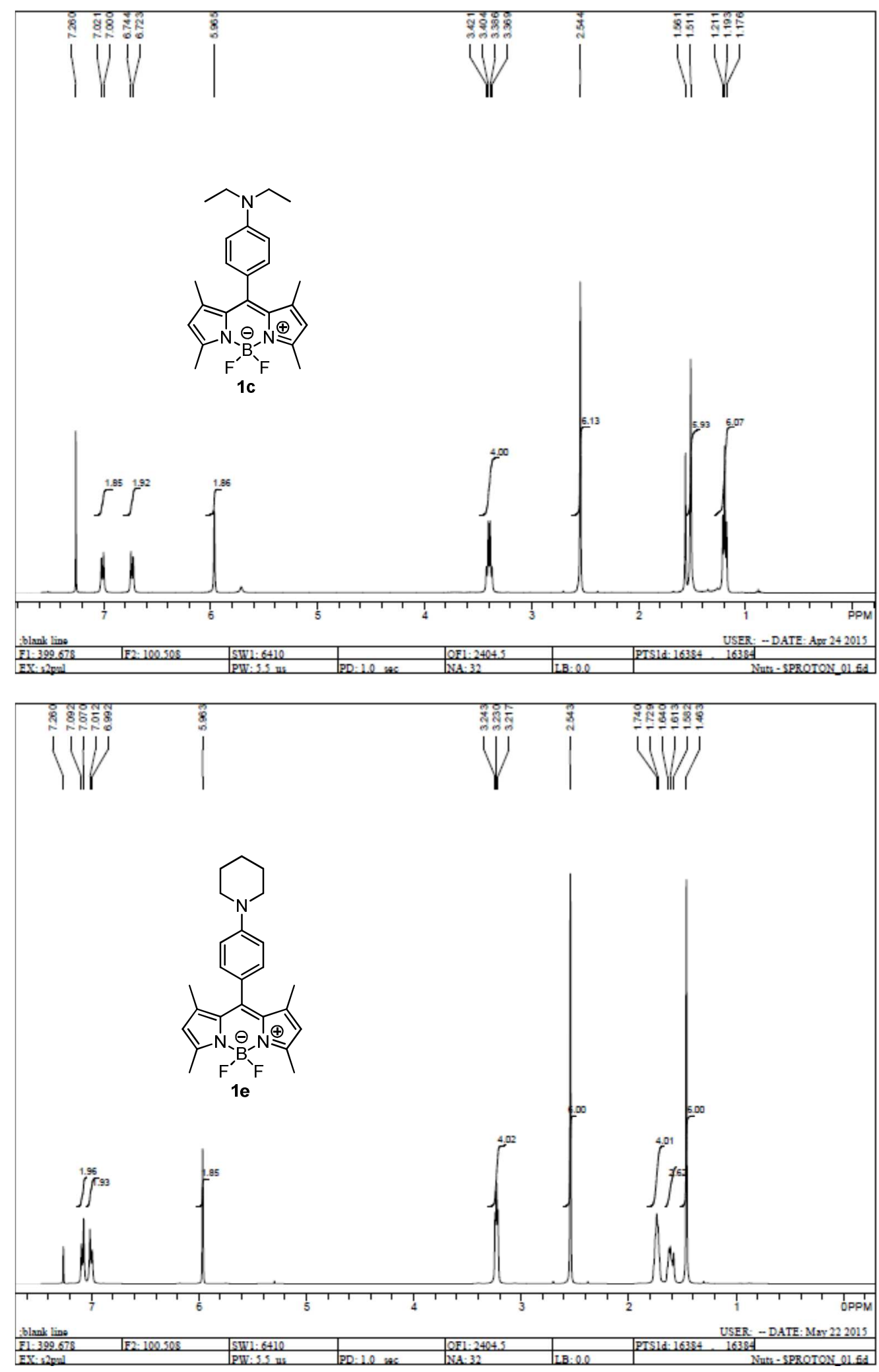

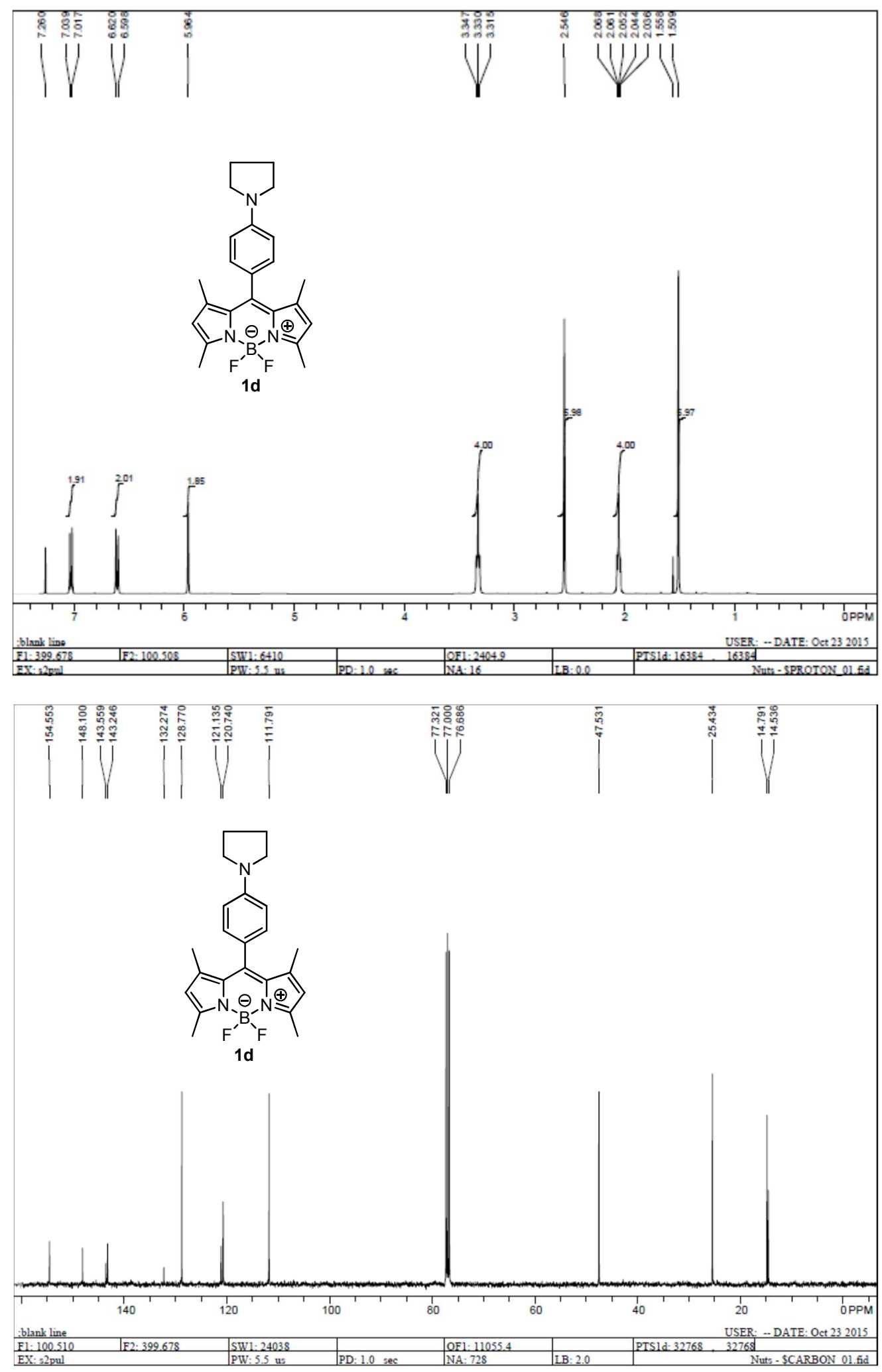

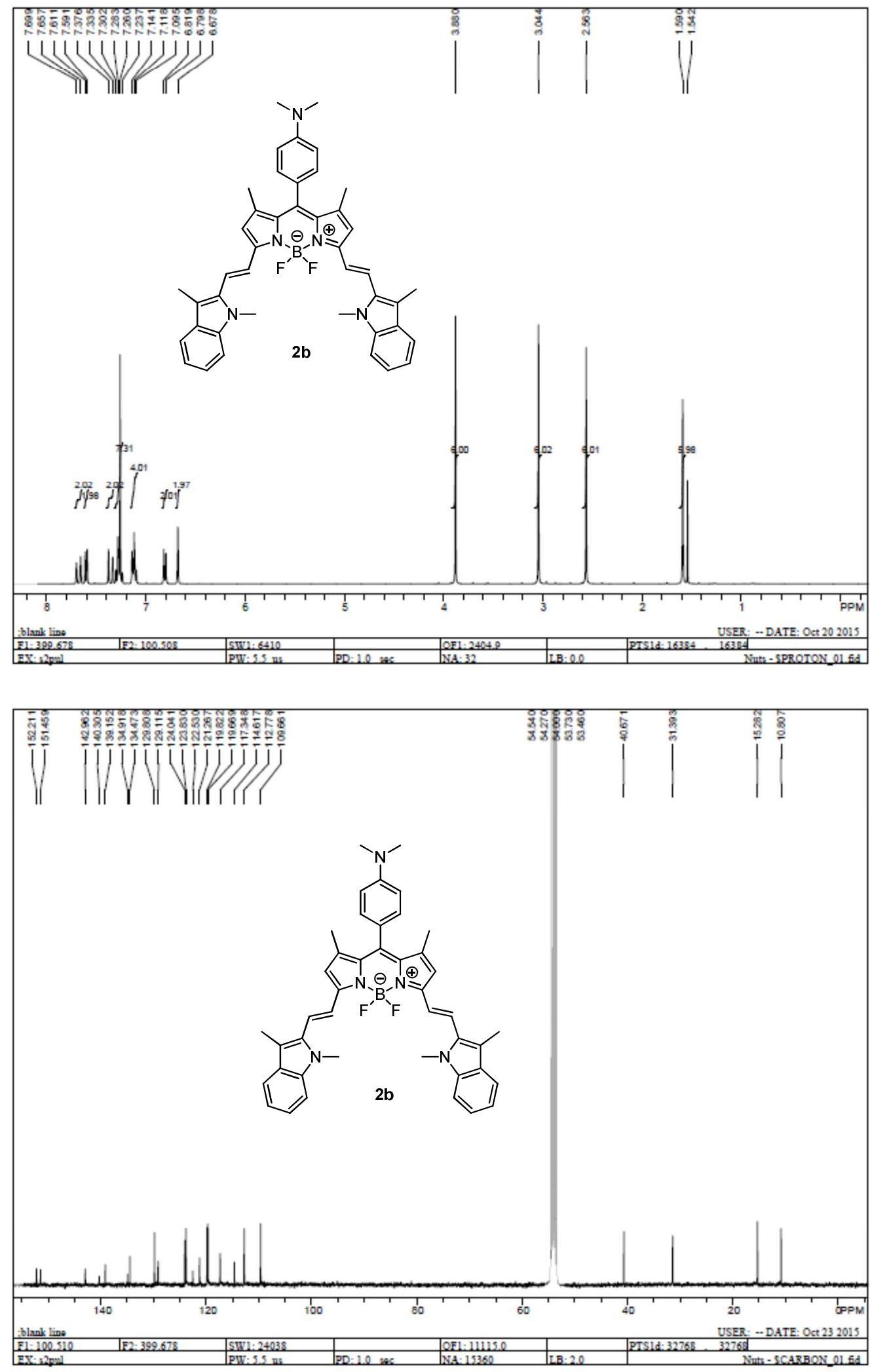

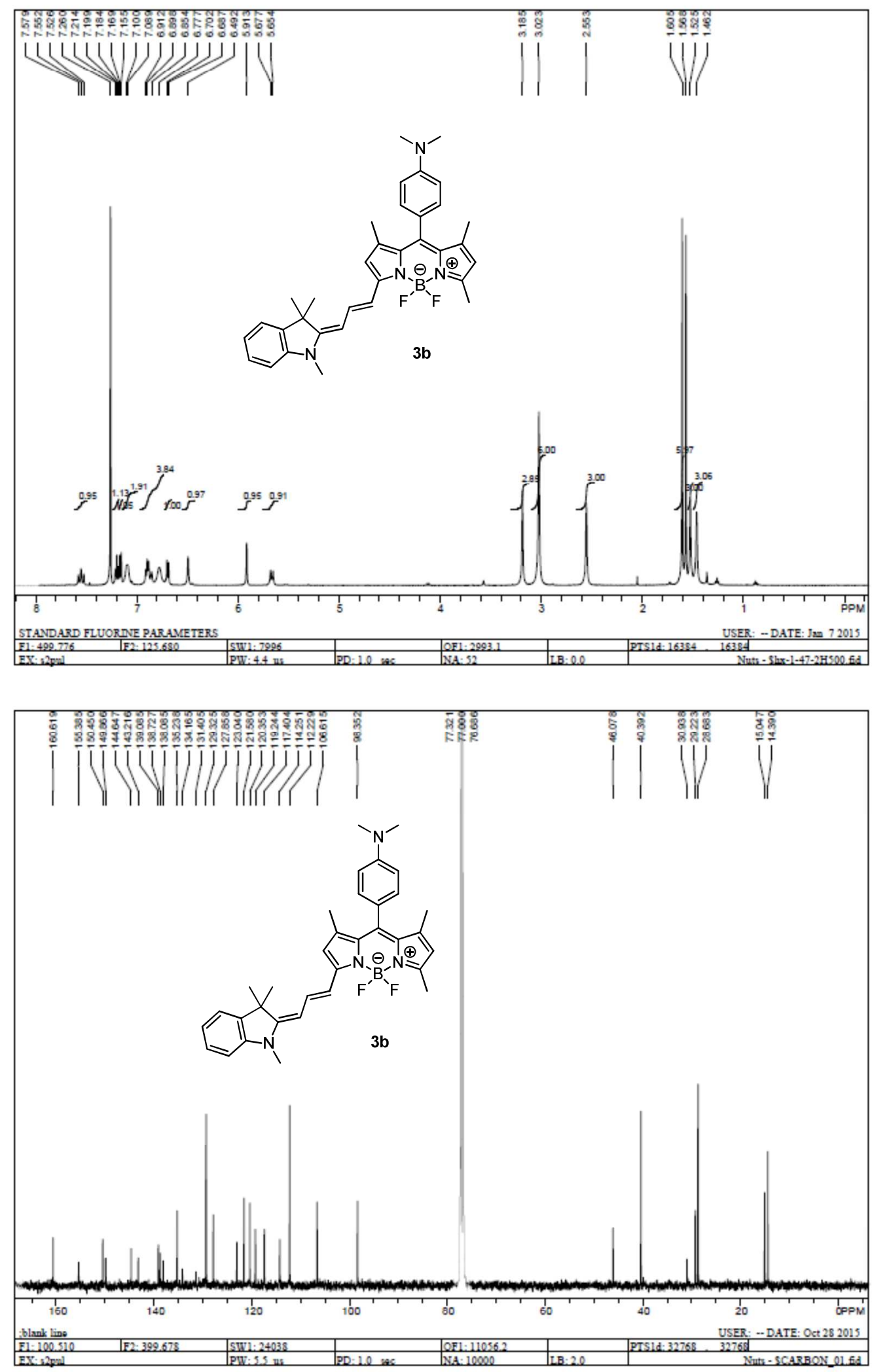

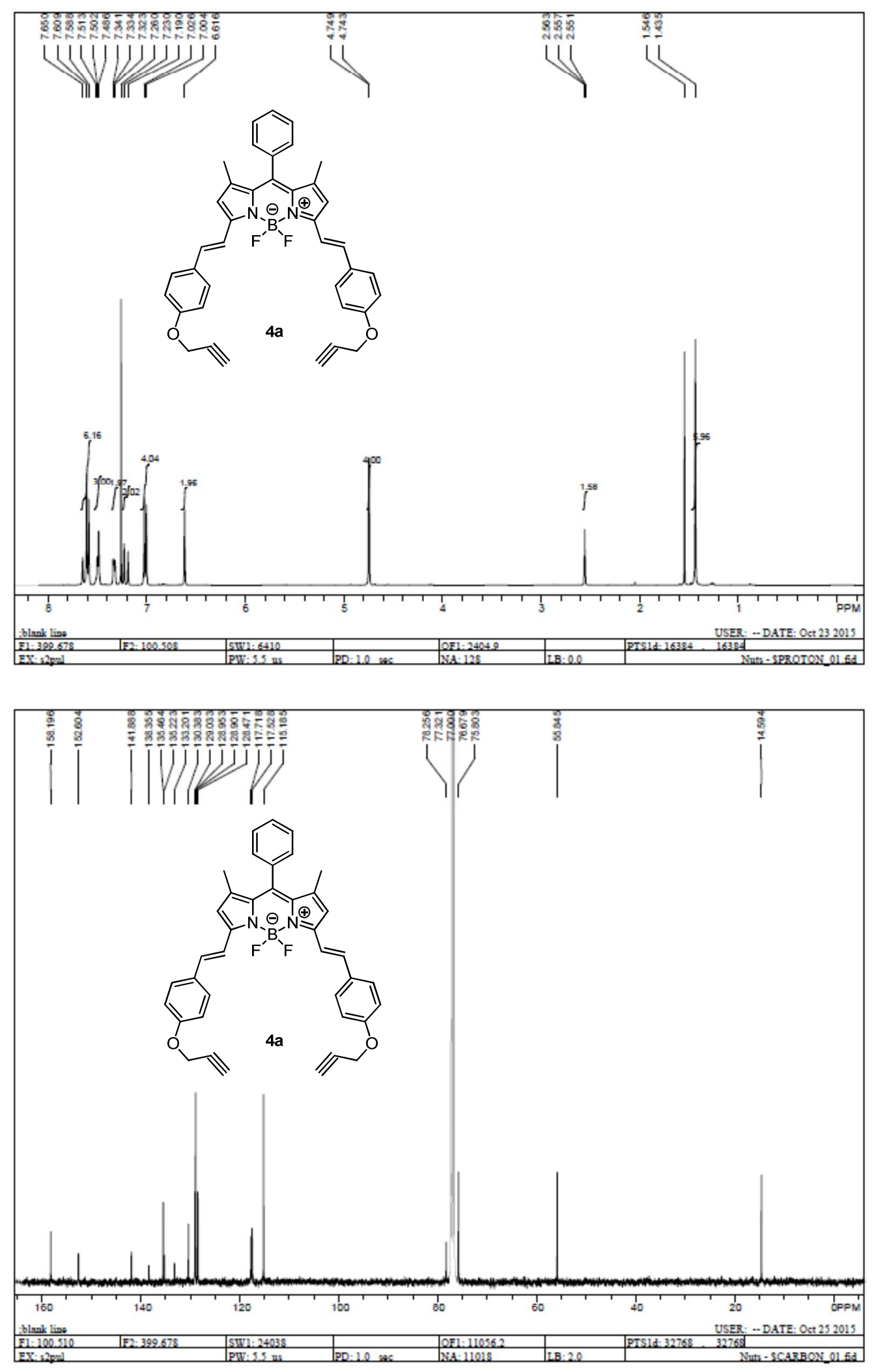

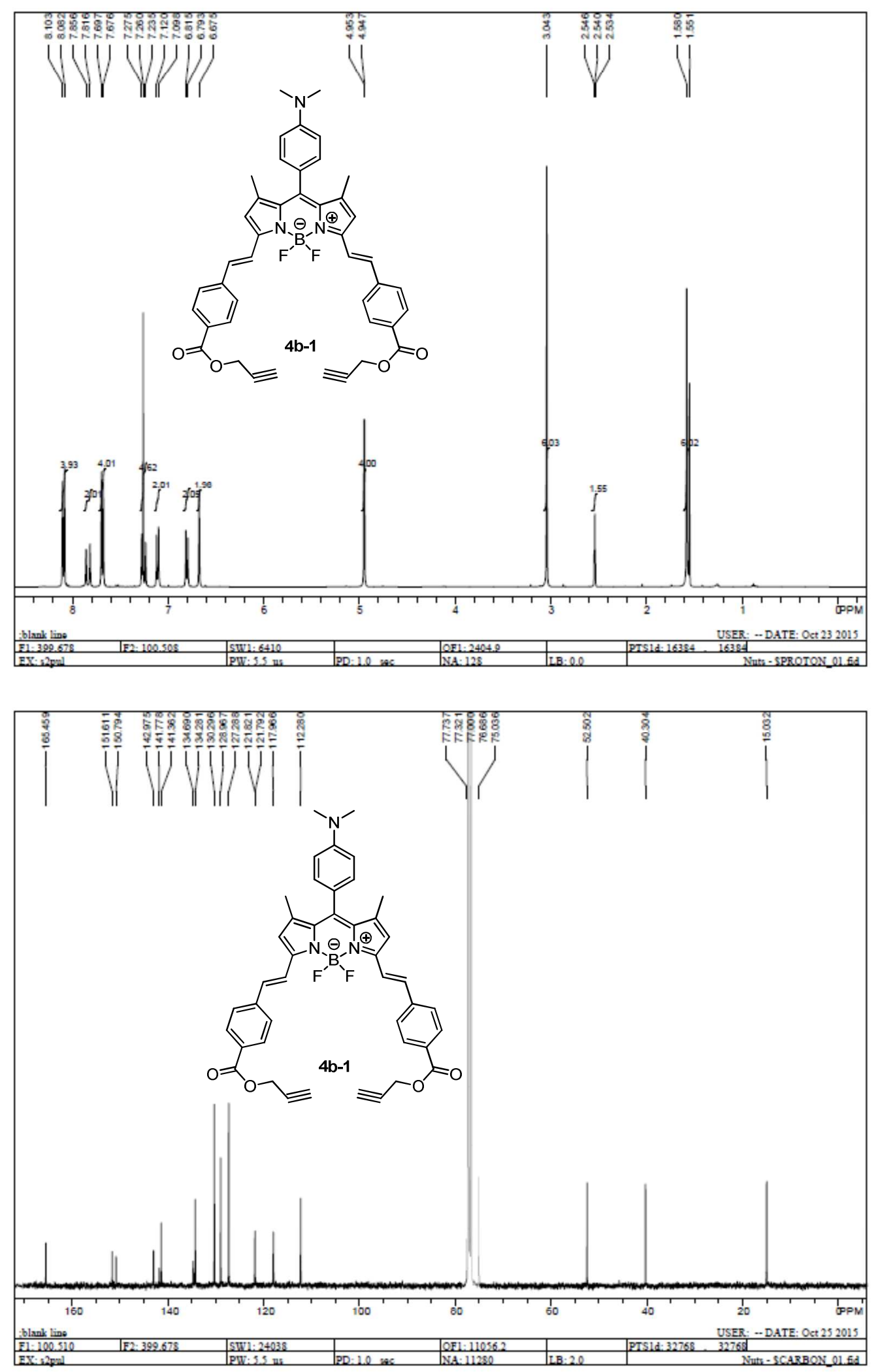

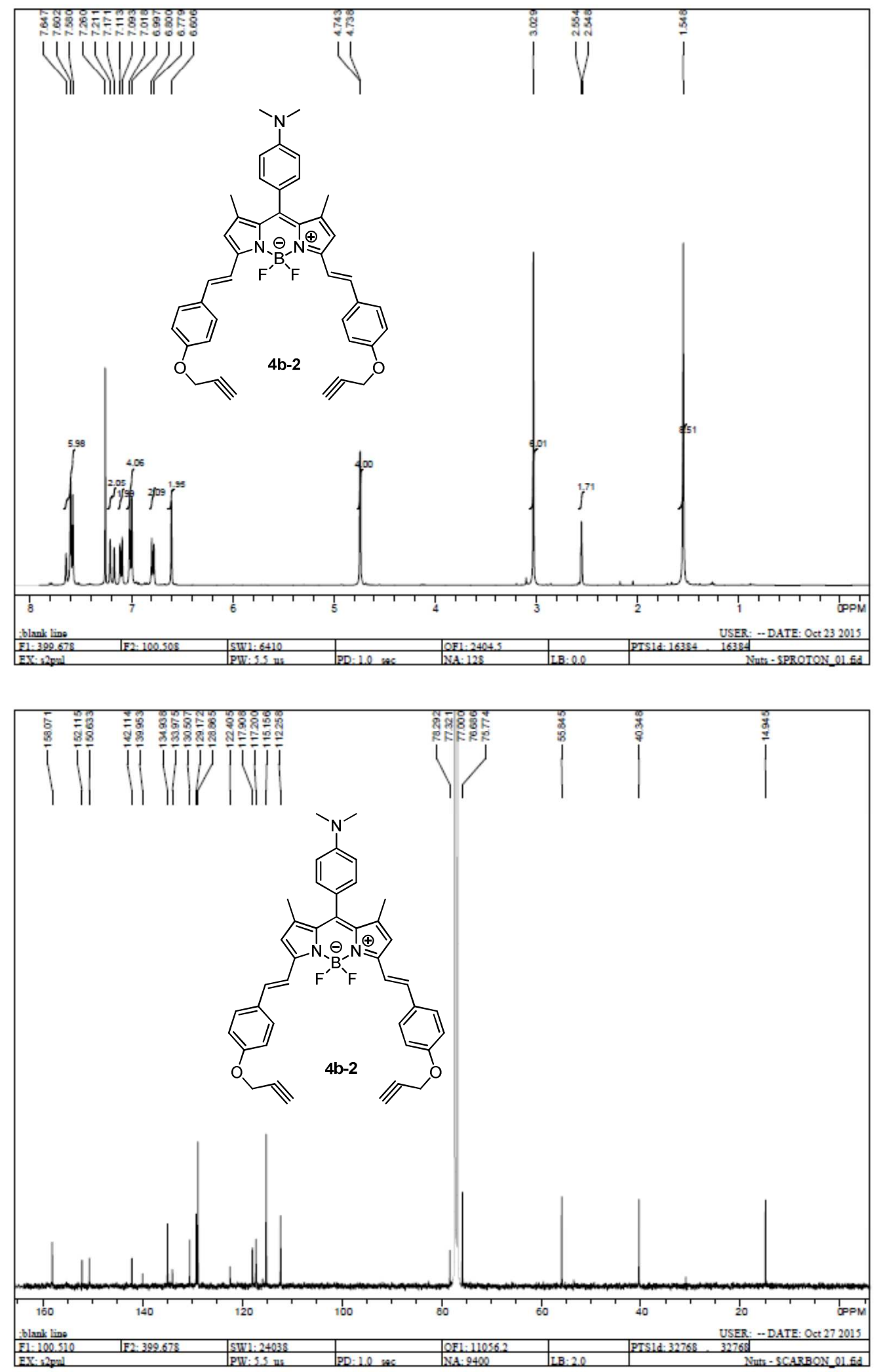

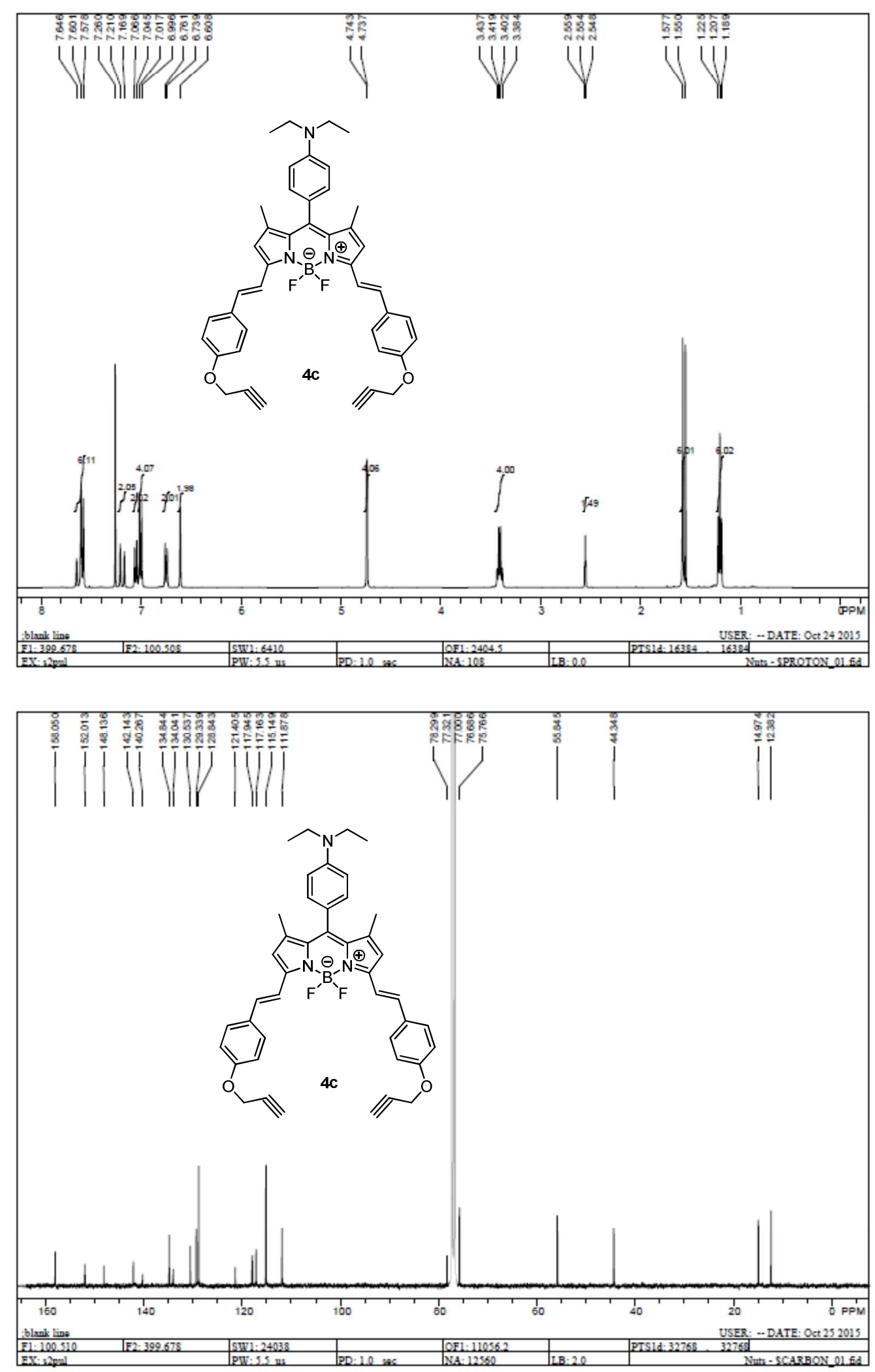

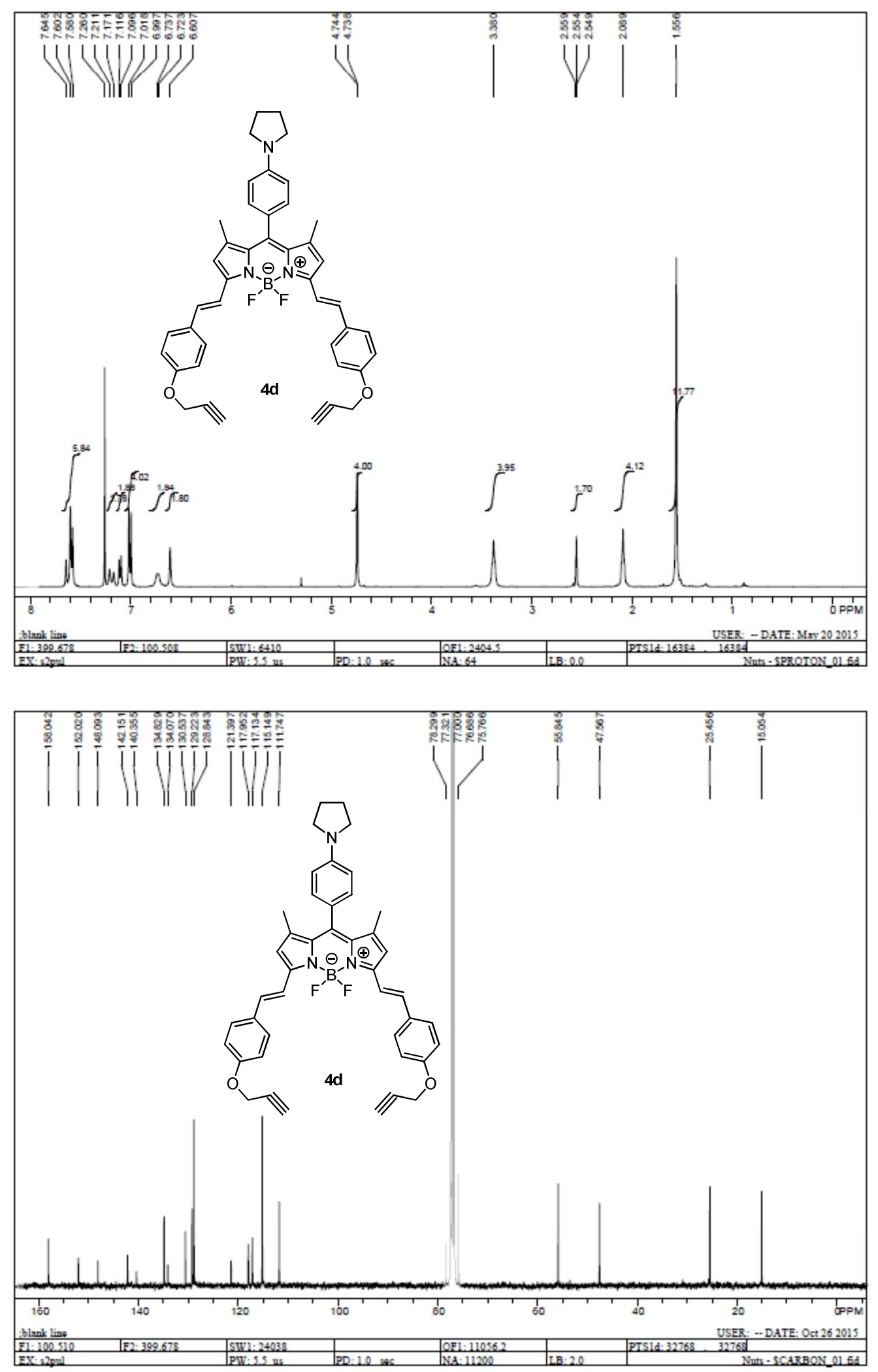

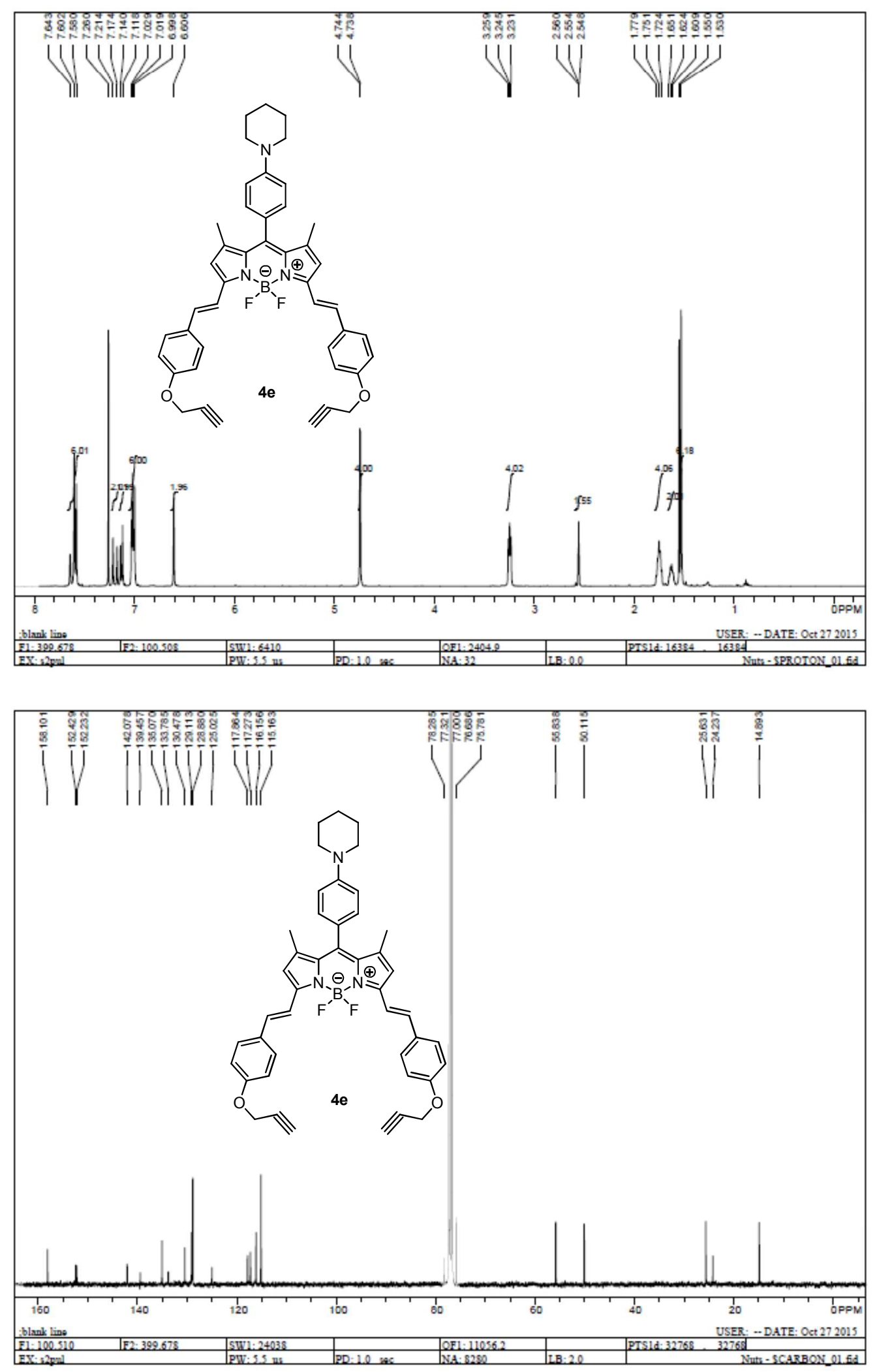

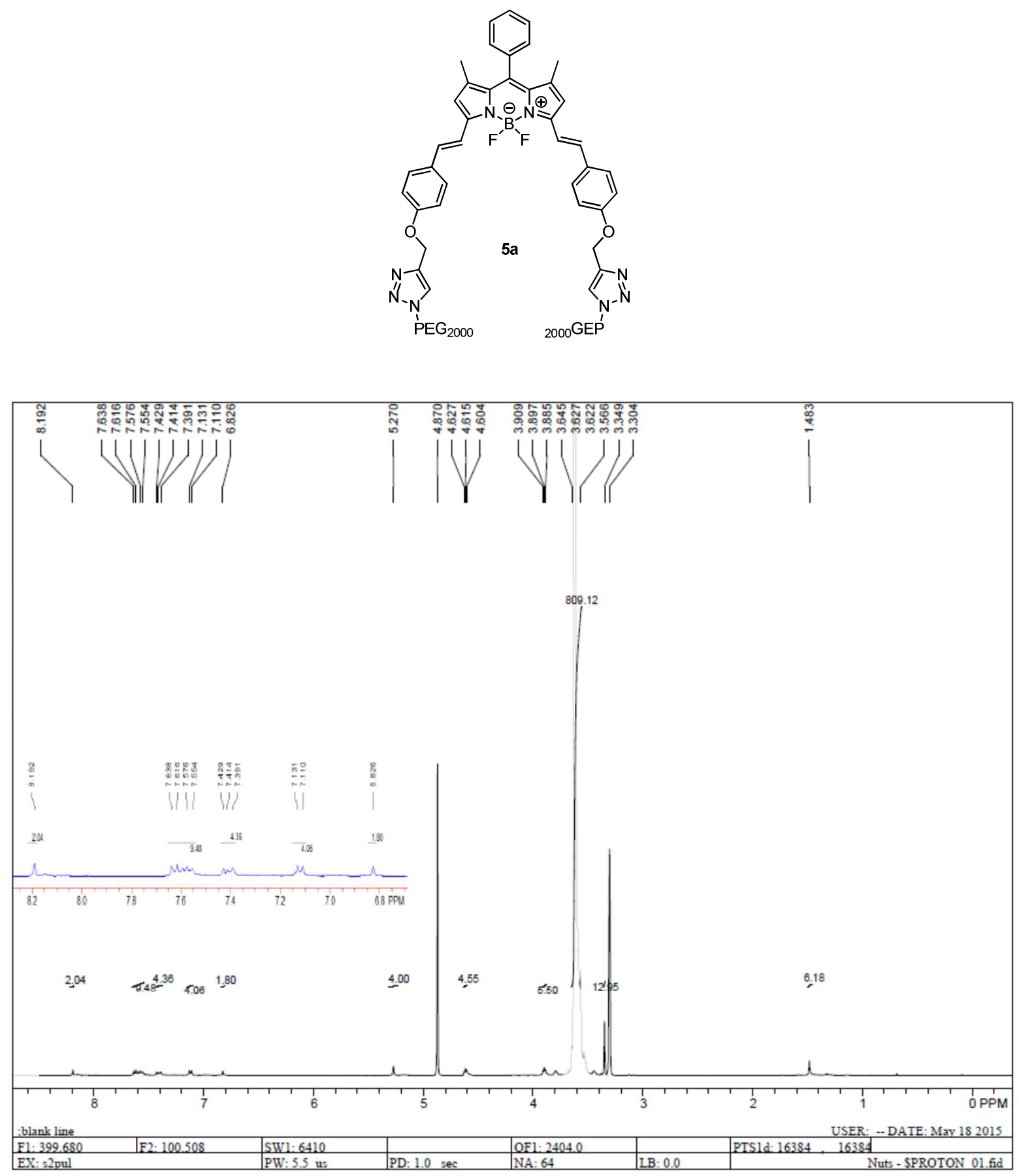

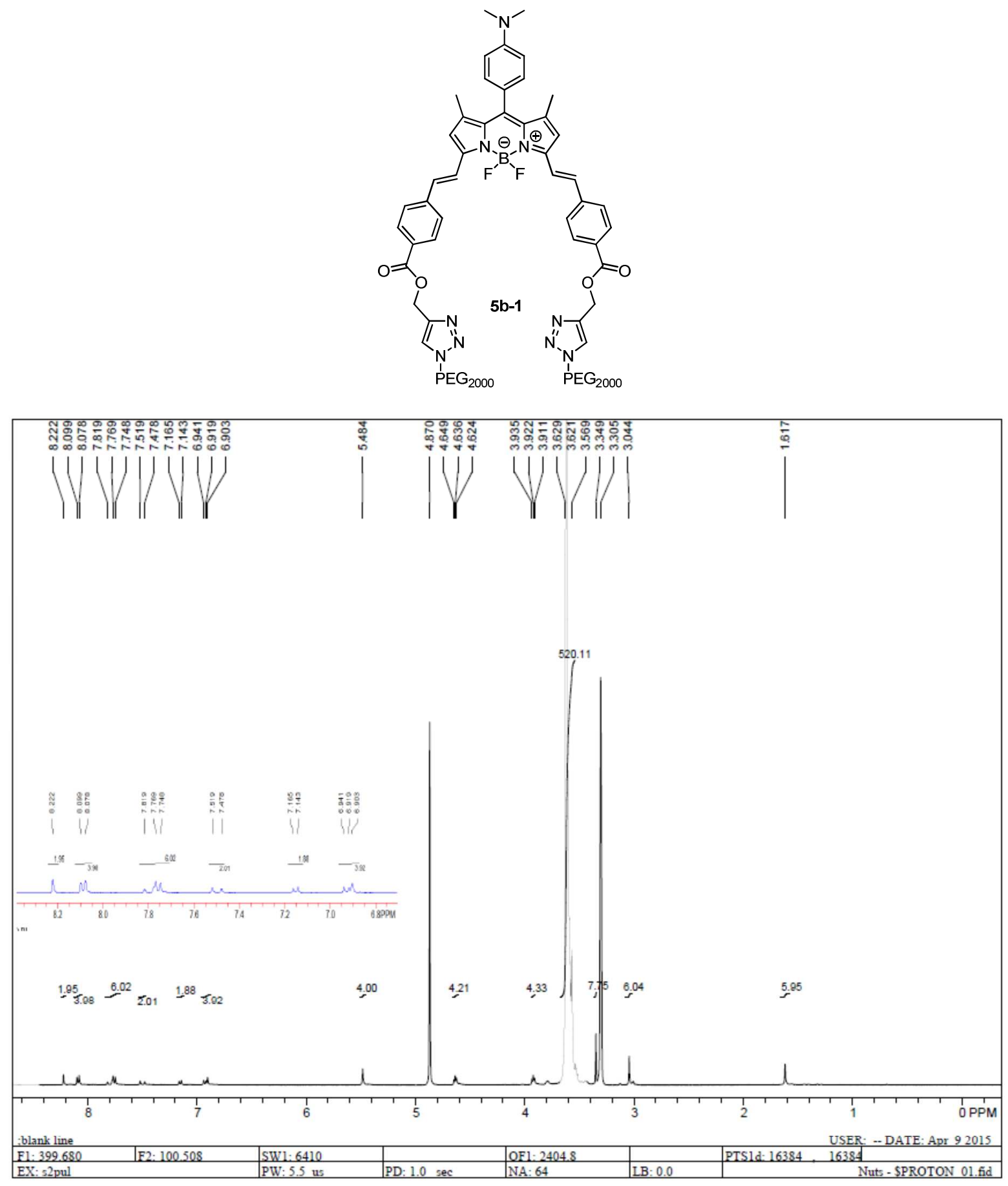


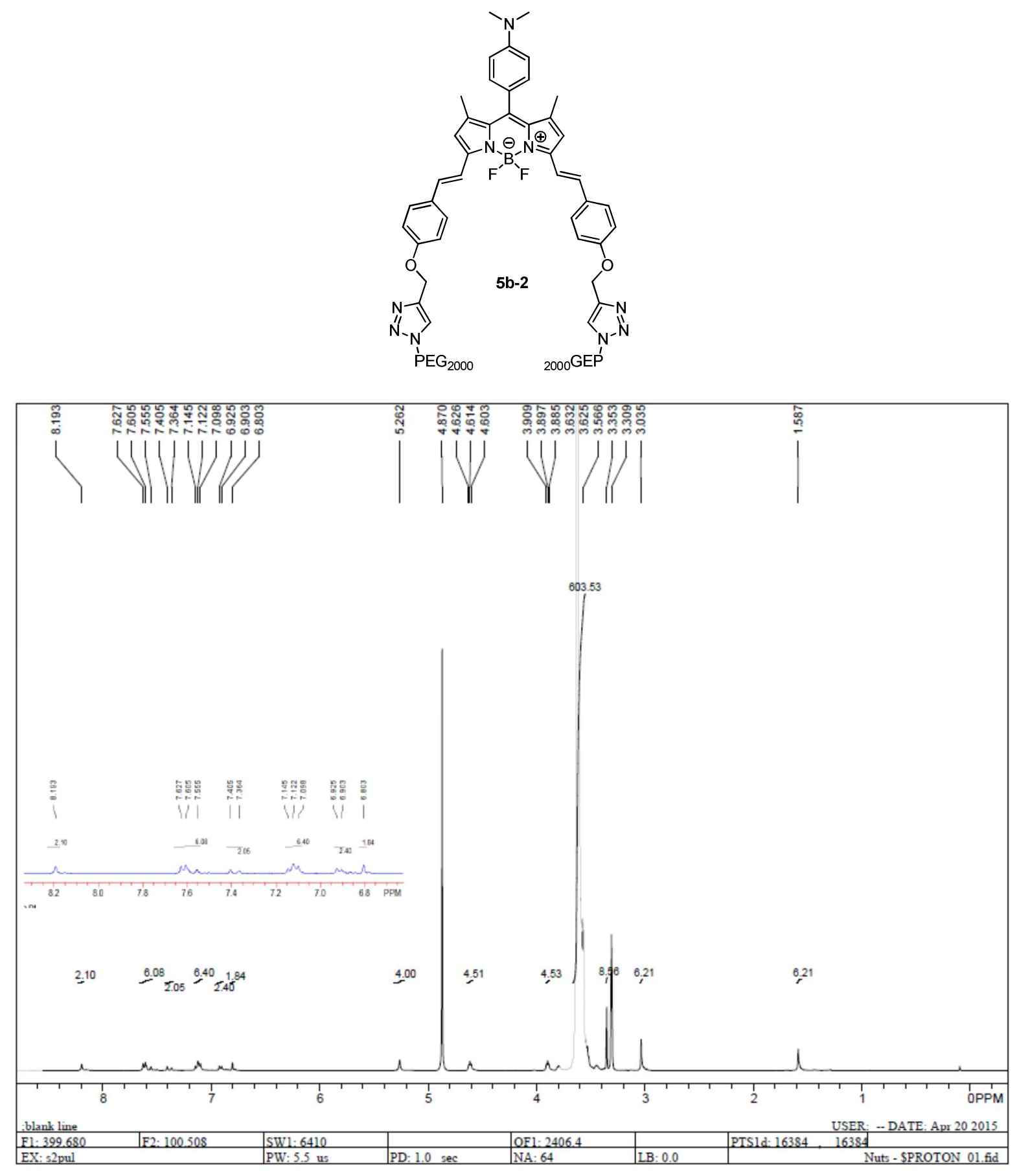



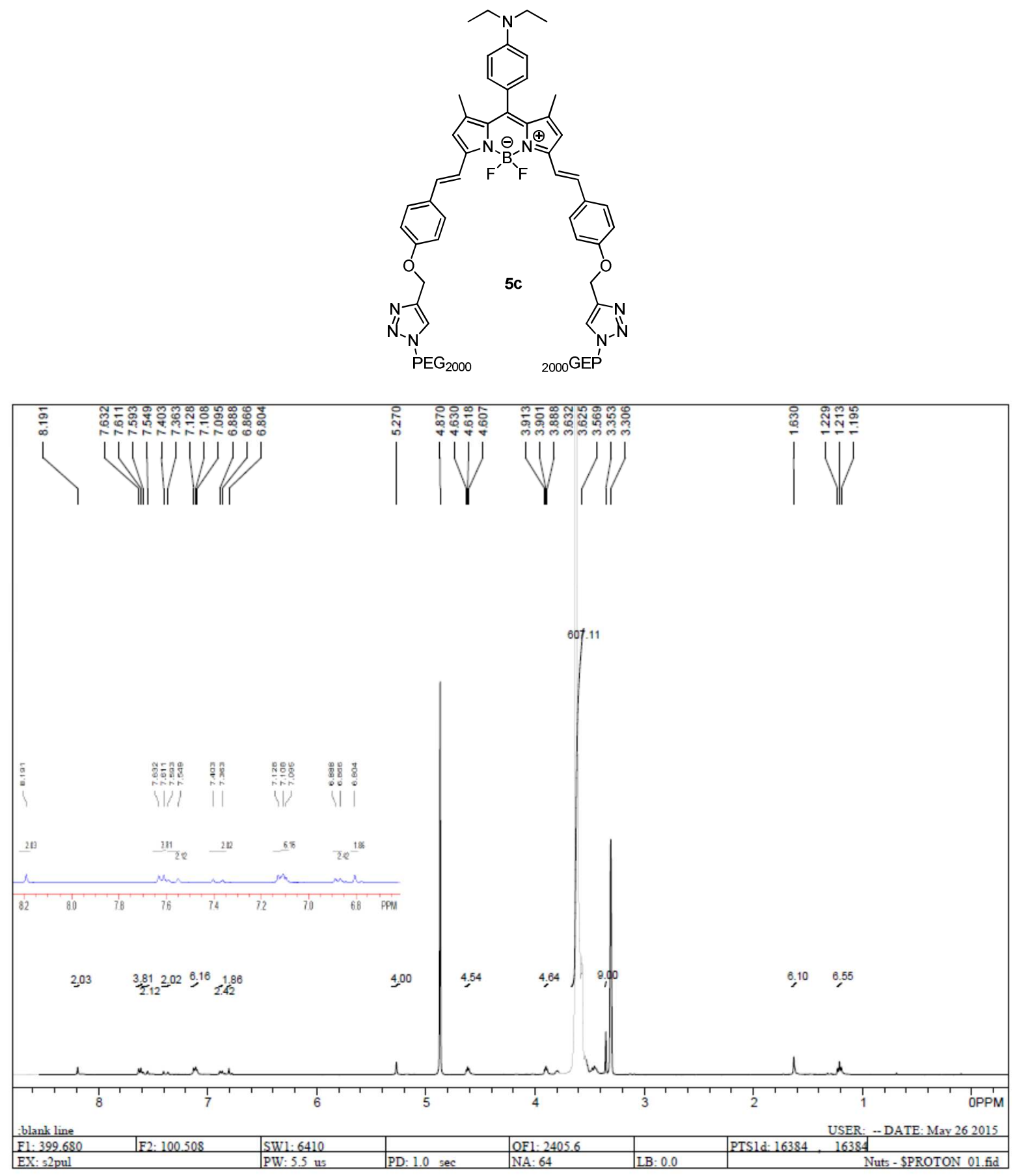


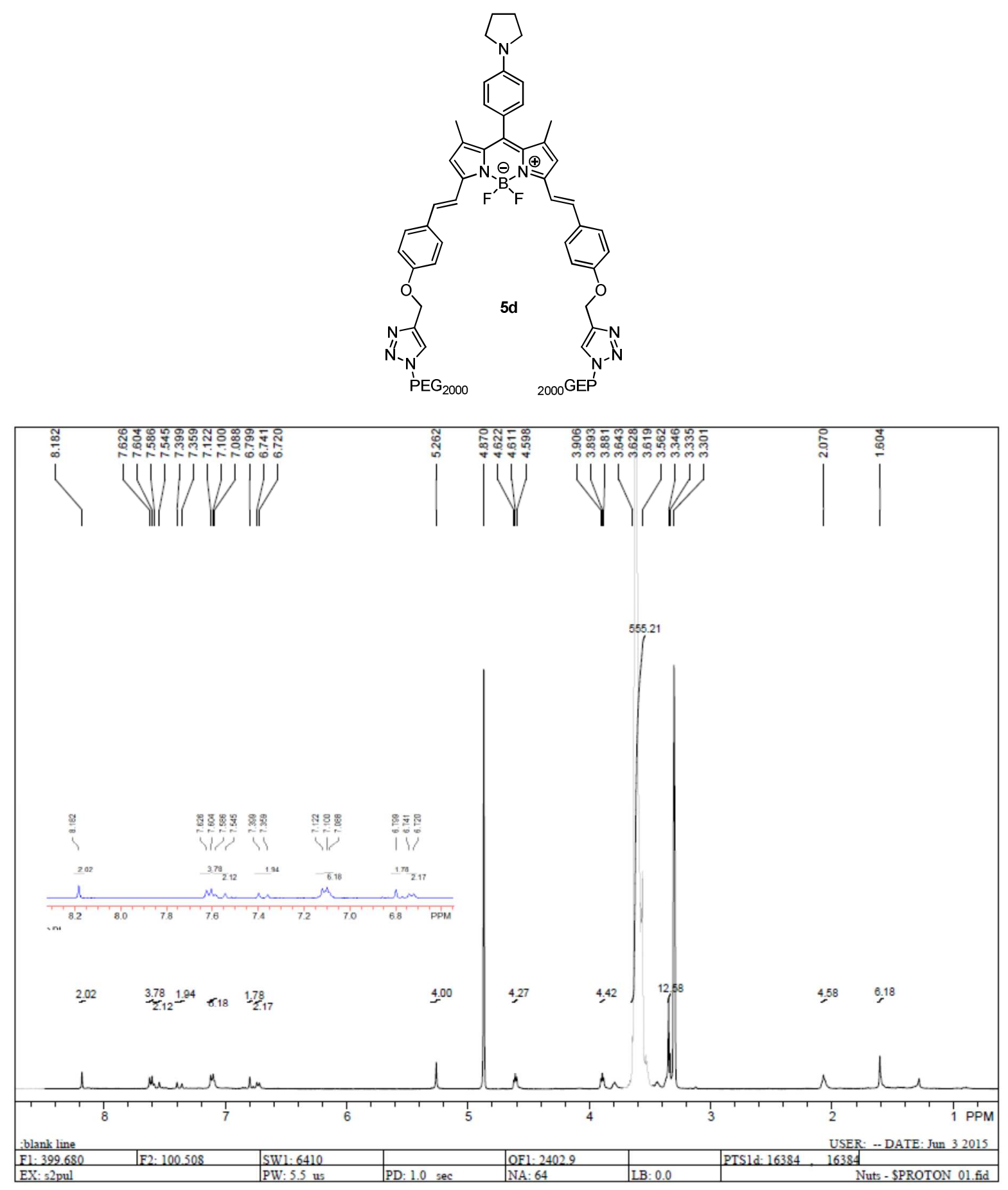



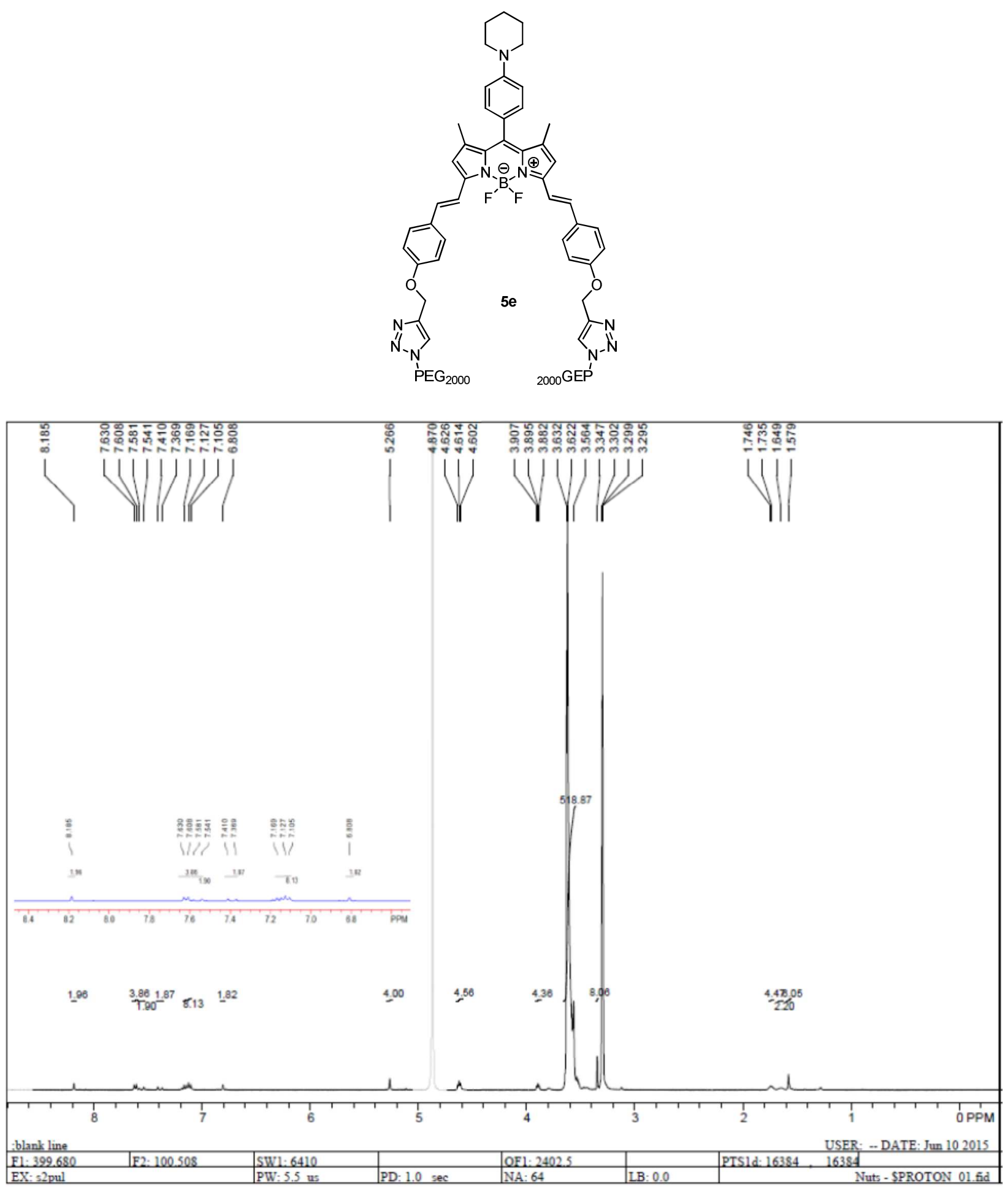


\section{References}

(1) Galangau, O.; Dumas-Verdes, C.; Méallet-Renault, R.; Clavier, G. Org. Biomol. Chem. 2010, 8,4546 .

(2) He, H.; Lo, P.-C.; Yeung, S.-L.; Fong, W.-P.; Ng, D. K. P. Chem. Commun. 2011, 47, 4748.

(3) Zheng, Q.; Xu, G.; Prasad, P. N. Chem. Eur. J. 2008, 14, 5812.

(4) Bura, T.; Retailleau, P.; Ulrich, G.; Ziessel, R. J. Org. Chem. 2011, 76, 1109.

(5) Urano, Y.; Asanuma, D.; Hama, Y.; Koyama, Y.; Barrett, T.; Kamiya, M.; Nagano, T.; Watanabe, T.; Hasegawa, A.; Choyke, P. L.; Kobayashi, H. Nat. Med. 2009, 15, 104.

(6) Shie, J.-J.; Liu, Y.-C.; Lee, Y.-M.; Lim, C.; Fang, J.-M.; Wong, C.-H. J. Am. Chem. Soc. 2014, 136, 9953. 